Bernath-Plaisted, J. S., A. O. Panjabi, N. A. Guido, K. D. Bell, N. Drilling, E. H. Strasser, S. K. Johnson, and M. D. Correll. 2021. Quantifying multiple breeding vital rates in two declining grassland songbirds. Avian Conservation and Ecology 16(1):19. https://doi.org/10.5751/ ACE-01875-160119

Copyright $(\mathcal{C} 2021$ by the author(s). Published here under license by the Resilience Alliance.

Research Paper

\title{
Quantifying multiple breeding vital rates in two declining grassland songbirds
}

Jacy S. Bernath-Plaisted ${ }^{1,2}$, Arvind O. Panjabi ${ }^{1}$, Nicole A. Guido ${ }^{1}$, Kelsey D. Bell ${ }^{1,3}$, Nancy E. Drilling ${ }^{1}$, Erin H. Strasser ${ }^{1}$, Sandra K. Johnson ${ }^{4}$ and Maureen D. Correll ${ }^{1,5}$

${ }^{1}$ Bird Conservancy of the Rockies, Brighton CO, USA, ${ }^{2}$ University of Madison-Wisconsin, Department of Forest and Wildlife Ecology, Madison WI 53706, USA, ${ }^{3}$ University of Regina, Department of Biology, Regina SK, Canada, ${ }^{4}$ North Dakota Game and Fish Department, Bismarck ND, USA, ${ }^{5}$ US Fish and Wildlife Service, MA USA

\begin{abstract}
Many studies of reproductive success in North American songbirds have focused on nesting success, while relatively few have evaluated breeding-season adult survival and post-fledging survival. Grassland songbirds are among North America's most rapidly declining avian groups, and knowledge of factors that influence vital rates is needed to address declines, develop management strategies, and accurately model population limitation. We concurrently monitored nesting success, breeding-season adult survival, and postfledging survival of two grassland obligates, Baird's Sparrow and Grasshopper sparrow, breeding in western North Dakota and northeastern Montana. Nesting success was monitored by locating and visiting nests at regular intervals while adult and post-fledging survival were assessed by daily telemetry tracking of radio-tagged birds. We analyzed the three variables using logistic exposure and modeled climate, temporal, and vegetative covariates to explain variation in rates. Cumulative nesting success, breeding-season adult survival, and post-fledging survival were 37\%,78\%, and 25\%, respectively, for Baird's Sparrow and 16\%, 74\%, and 55\% for Grasshopper Sparrow. Both nesting success and post-fledging survival in Baird's Sparrow were responsive to environmental covariates including temporal effects and vertical vegetation structure. Conversely, vital rates of Grasshopper Sparrow were largely unresponsive to covariates we modeled, perhaps because of the species' broader habitat niche relative to Baird's Sparrow. Breeding season adult survival in both species showed little annual variation and was high relative to overwintering survival estimates for the same species, while post-fledging survival in Baird's Sparrow was low and may be a management concern. We suggest as a next step the formal comparison of vital rates across life-stages in an integrated population model capable of identifying sources of population limitation throughout the full annual cycle of the species.
\end{abstract}

\section{Mesure de divers taux vitaux de reproduction chez deux passereaux de prairie en diminution}

RÉSUMÉ. De nombreuses études sur le succès de reproduction des passereaux d'Amérique du Nord se sont penchées sur le succès de nidification, mais relativement peu d'études ont évalué la survie des adultes en période de nidification et la survie après l'envol. Les passereaux de prairie font partie des groupes d'oiseaux qui diminuent le plus rapidement en Amérique du Nord et il est nécessaire de connaître les facteurs qui influent sur les taux vitaux pour renverser les déclins, élaborer des stratégies de gestion et modéliser avec précision ce qui limite les populations. Nous avons suivi simultanément le succès de nidification, la survie des adultes pendant la saison de reproduction et la survie après l'envol chez deux espèces spécialistes de prairie, le Bruant de Baird et le Bruant sauterelle, se reproduisant dans l'ouest du Dakota du Nord et le nord-est du Montana. Le succès de nidification a été mesuré en localisant et visitant les nids à intervalles réguliers, tandis que la survie des adultes et la survie après l'envol ont été calculées au moyen du suivi télémétrique quotidien d'oiseaux munis d'un émetteur. Nous avons analysé ces trois variables au moyen de l'exposition logistique et modélisé les covariables climatiques, temporelles et végétales pour expliquer la variation des taux. Le succès cumulatif de la nidification, la survie des adultes en saison de reproduction et la survie après l'envol étaient respectivement de $37 \%, 78 \%$ et $25 \%$ pour le Bruant de Baird, et de $16 \%$, $74 \%$ et $55 \%$ pour le Bruant sauterelle. Le succès de nidification et la survie après l'envol du Bruant de Baird étaient sensibles aux covariables environnementales, y compris les effets temporels et la structure verticale de la végétation. À l'inverse, les taux vitaux du Bruant sauterelle ne variaient pas en fonction des covariables que nous avons modélisées, peut-être en raison de la niche d'habitat plus élargie de cette espèce comparativement au Bruant de Baird. La survie des adultes en saison de reproduction chez les deux espèces a montré peu de variation annuelle et était élevée par rapport à leur taux de survie en hiver, tandis que la survie après l'envol chez le Bruant de Baird était faible et devrait peut-être être une préoccupation à prioriser. Comme prochaine étape, nous proposons de comparer de façon formelle les taux vitaux à travers les étapes de vie dans un modèle de population intégré permettant d'identifier les facteurs qui limitent les populations tout au long du cycle annuel complet de ces deux espèces.

Key Words: Adult survival; Ammodramus savannarum; Baird's Sparrow; Centronyx bairdii; demography; Grasshopper Sparrow; grassland birds; post-fledging survival; nesting success; Northern Great Plains 


\section{INTRODUCTION}

Accurate demographic rates are fundamental to our understanding of species ecology (Pulliam 1988, Murdoch 1994) particularly when reversing population decline is a management goal (Anders and Marshall 2005). Avian population dynamics are influenced by multiple vital rates and life-history traits (Clark and Martin 2007). These include not only those that are directly tied to fecundity, such as nesting success and clutch-size, but also rates that affect recruitment to death ratios and lifetime reproductive success, such as adult and juvenile survival (Stahl and Oli 2006, Clark and Martin 2007). Vital rates may display both spatial and temporal variation, changing across environmental conditions and throughout the annual cycle of species (Rushing et al. 2017). Therefore, addressing species declines often requires a complete understanding of vital rates that influence population dynamics (Fletcher et al. 2006), and in some cases, failure to assess multiple rates can result in the overlooking of life-history phases that are critical for management (Crouse et al. 1987). Although species abundance data can be effectively used to track population changes over time (e.g., Rosenberg et al. 2019), field-collected data describing vital rate performance under different habitat conditions, and at different life-stages, may be needed to understand population changes mechanistically (Donovan et al. 1995, McCoy et al. 1999, Eng et al. 2011).

Among North American songbirds, breeding-season reproductive studies often focus on nesting success, ignoring adult and postfledging survival (Streby and Andersen 2011). This oversight is likely due in part to the difficulty and cost associated with tracking individual birds within and across seasons (Kershner et al. 2004, Suedkamp Wells et al. 2007, Rush and Stutchbury 2008, Cox et al. 2014). Yet, in populations of avian species, both adult and post-fledging survival can influence population dynamics (Pulliam et al. 1992, Anders and Marshall 2005, Fletcher et al. 2006, Bonnot et al. 2011, Cox et al. 2014) and the importance of these vital rates often vary among species (Stahl and Oli 2006). Further, habitat requirements can differ among life-history stages, thus managing for a single vital rate may be inadequate. For example, good foraging habitat for adults may differ from highquality nest sites (Steele 1993) while fledglings may select habitat cover that differs from adult preferences or changes with age (Jones and Bock 2005, Small et al. 2015). If habitat preference is linked to fitness in any respect (Chalfoun and Schmidt 2012), it is reasonable to expect that response to environmental conditions among vital rates may differ accordingly. Therefore, there is a need to examine the effect of environmental covariates on multiple vital rates within populations both to guide management (Perlut et al. 2008a, Young et al. 2019) and to provide baseline data for the construction of accurate population models (Streby and Andersen 2011).

North America's grassland obligate songbirds provide a relevant model system to explore the importance of monitoring multiple vital rates, as many species within this group are both steeply declining and have been poorly studied with respect to adult and juvenile survival. Despite increased attention in recent decades, grassland songbirds and their habitats remain in crisis (Askins et al. 2007, North American Bird Conservation Initiative 2009, Green et al. 2018). This assemblage of species has experienced steep declines documented from the advent of the Breeding Bird Survey (Rosenberg et al. 2019) and faces a wide variety of threats on both the breeding and wintering grounds. These threats include habitat loss through conversion to agriculture, climate change, fragmentation and disturbance associated with energy development, shrub encroachment, non-native plant species, and disruption of historic fire and grazing regimes (see Brennan and Kuvlesky 2005, Askins et al. 2007, North American Bird Conservation Initiative 2009). Although declines among grassland birds are broadly understood to be driven by agricultural land conversion (Murphy 2003, Pool et al. 2014, Hill et al. 2014), more information on vital rates is required to develop effective, species-level, management strategies for implementation in remaining grassland habitats (e.g., Davis 2003, Fletcher et al. 2006, Perlut et al. 2008a).

The mixed-grass prairie of the Northern Great Plains (NGP) is one of the largest and most intact areas of grassland in North America, though today only $50 \%$ of its historic $600,000 \mathrm{~km}^{2}$ extent remains (Comer et al. 2018). Still, this eco-region is critical breeding habitat for an assemblage of 26 grassland obligate bird species (Askins et al. 2007). We focused our demographic research on two species belonging to this group: Baird's Sparrow (Centronyx bairdii) and Grasshopper Sparrow (Ammodramus savannarum). Both species have suffered population losses of more than $60 \%$ since 1970 (Sauer et al. 2017) and both are species of management concern for multiple states and provinces in the Great Plains region (Green et al. 2018). The two species share similar habitat preferences and reproductive ecology in the NGP (Jones et al. 2010, Lipsey and Naugle 2017) and both are shortdistance migrants that winter in the desert grasslands of the southwestern United States and Northern Mexico (Vickery 1996, Green et al. 2002). However, despite apparent ecological similarities, the two species also present an interesting contrast with respect to degree of habitat specialism (Correll et al. 2019); Baird's Sparrow is narrowly range-restricted to the NGP (however see Youngberg et al. 2020) and highly specialized to mixed-grass prairie ecosystems during the breeding season (see Green et al. 2002) while Grasshopper Sparrow is continently distributed and found in a greater variety of surrogate grasslands and opencountry habitats (Vickery 1996).

Although the nesting ecologies of these species have been wellstudied (e.g., Davis and Sealy 1998, Davis 2003, Jones et al. 2010, Davis et al. 2016), estimates of nesting success in grassland species can vary with climate conditions (George et al. 1992, Skagen and Adams 2012, Conrey et al. 2016, Zuckerberg et al. 2018) as well as habitat and management treatments (e.g., Davis 2005, Lloyd and Martin 2005, Hovick et al. 2012, C. A. Davis et al. 2016, Pipher et al. 2016). Replicate studies, and those that examine both annual and within season variation, therefore remain valuable. Moreover, estimates of both adult and post-fledging survival are few, or lacking entirely, for many grassland birds. There are currently no published estimates of within breeding-season adult survival for Baird's Sparrow or Grasshopper Sparrow. Several studies of annual adult survival in Grasshopper Sparrow have been conducted in eastern populations (Perkins and Vickery 2001, Balent and Norment 2003), but these rely on mark-recapture techniques and thus survival estimates are considered apparent because mortality cannot be distinguished from emigration (Lebreton et al. 1992). Research on post-fledging survival is also limited, with no estimates existing for Baird's Sparrow and only a single study of post-fledging survival in Grasshopper Sparrow 
(Hovick et al. 2011). Only one study to our knowledge has attempted to address the nesting, adult, and post-fledging lifestages simultaneously in a grassland bird species (van Vliet et al. 2020).

To address these knowledge gaps, we conducted a multi-year study to jointly examine the rates and drivers of nesting success (4 years), breeding-season adult survival (3 years), and post-fledging survival (3 years) in single populations of Baird's and Grasshopper Sparrows. We defined adult breeding-season survival as the probability of surviving for 90 days on the breeding grounds and post-fledging survival as the probability of surviving for 20 days, the approximate age of independence. We conducted nest monitoring and radio-telemetry tracking of adult and fledgling birds at two sites in the NGP, one in western North Dakota (2015-2018) and the other in northeastern Montana (2016-2018). Broadly, we hypothesized that there would be variation in rates and drivers among life-history phases, as there are potential differences in predation pressure, vegetation structural requirements, and sensitivity to climate exposure across these stages (Jones and Bock 2005, Low et al. 2010, McCauley et al. 2017, Zuckerberg et al. 2018). We predicted that, overall, greater within-season precipitation would result in more productive range conditions (Barnett and Facey 2016), and thus higher survival across all stages (Conrey et al. 2016), despite some negative effects of extreme precipitation events (Carver et al. 2017). We also predicted that nests of both species would benefit from taller and more dense vegetation cover, given the species' habitat-preferences in the region (Lipsey and Naugle 2017) and potential benefits of concealment. Similarly, we predicted that fledglings of both species would benefit from taller and denser vegetation (e.g., Fisher and Davis 2011, Hovick et al. 2011) which can provide more cover from predators and weather exposure in the vulnerable early postfledging phase (Jones and Bock 2005). Finally, we predicted that fledglings of both species would be sensitive to within-season temperature and precipitation, as fledgling grassland birds can be affected by climate conditions (e.g., Adams et al. 2006) and likely have a limited ability to thermoregulate relative to adults. Our study is the first to concurrently examine all three vital rates in breeding populations of these species and provides insight into the effects of habitat conditions across life-history stages.

\section{METHODS}

\section{Study area}

We conducted our study at two mixed-grass prairie sites (Fig. 1): one located in Golden Valley County, western North Dakota $\left(46^{\circ}\right.$ $37^{\prime} \mathrm{N}, 103^{\circ} 59^{\prime} \mathrm{W}$; elevation $\sim 863 \mathrm{~m}$ ), and the other in Valley County, northeastern Montana ( $48^{\circ} 39^{\prime} \mathrm{N}, 106^{\circ} 28^{\prime} \mathrm{W}$; elevation $\sim 975 \mathrm{~m}$ ). We conducted research activities on two pastures at each study site (4 total pastures); pastures ranged in size from 128-177 ha $(\overline{\mathrm{x}}=150.5, \mathrm{SD}=17.6)$. Private lands support $85 \%$ of remaining grassland habitat in North America (North American Bird Conservation Initiative 2013) and much of this land is directly tied to ranching in mixed-grass prairie regions (Lipsey and Naugle 2017). Therefore, in choosing site where grazing occurs, we sought to use plots that were reflective of grasslands in the Northern Great Plains (NGP). We selected pastures based on abundance of singing male focal species, and feasibility of land access. Both pastures at our North Dakota study site were located on the Little Missouri
National Grassland, managed by the U.S. Forest Service, while pastures at our Montana site were located both on private and U. S. Bureau of Land Management properties.

Fig. 1. Study site locations and species' ranges for demographic study of Baird's Sparrow and Grasshopper Sparrow in western North Dakota and northeastern Montana. Crosshatching indicates wintering range. Species ranges are sourced from BirdLife International and NatureServe 2016.

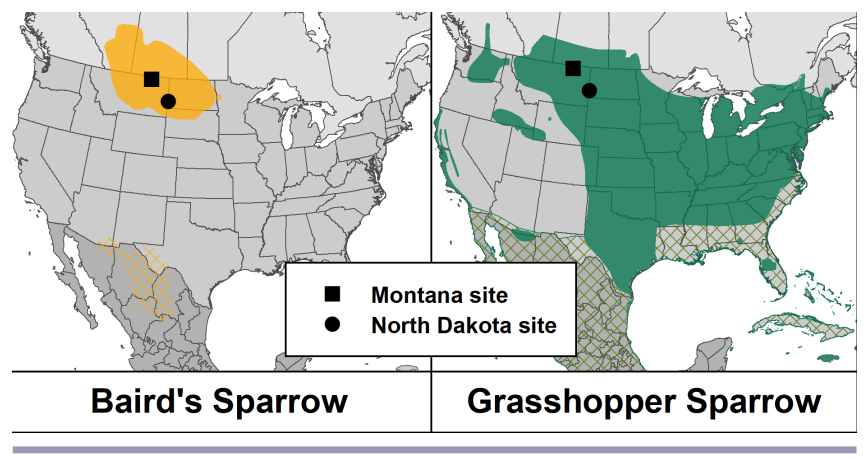

Pastures at both sites consisted of flat to moderately rolling hills, small seasonal wetlands, and sparse to patchy shrub-cover (e.g., Symphoricarpos occidentalis and Artemisia sp.). Vegetation at sites was predominantly a mixture of non-native, cool-season grasses and native, warm-season, mixed-grass prairie species as well as a diversity of primarily native forbs. Cool-season grasses included Kentucky Bluegrass (Poa pratensis), Crested Wheatgrass (Agropyron cristatum) and Smooth Brome (Bromus inermis); these three species comprised the majority of non-native plant cover at all sites. Native grasses included Blue Grama (Bouteloua gracilis), Western Wheatgrass (Agropyron smithii), Needle-and-thread Grass (Hesperostipa comata), Prairie June Grass (Koeleria macrantha), and Green Needlegrass (Nassella viridula). Our North Dakota and Montana sites differed substantially in average cover of non-native species $\left(\overline{\mathrm{x}}_{\mathrm{ND}}=49 \%, \mathrm{SD}=26 ; \overline{\mathrm{x}}_{\mathrm{MT}}=10 \%, \mathrm{SD}\right.$ $=19$ ). In addition to our avian focal species, other species of grassland songbird commonly breeding at sites included, Chestnut-collared Longspur (Calcarius ornatus), Sprague's Pipit (Anthus spragueii), Western Meadowlark (Sturnella neglecta), Savannah Sparrow (Passerculus sandwichensis), and Bobolink (Dolichonyx oryzivorus). Domestic cattle (Bos taurus) grazed intermittently at variable stocking rates on all pastures throughout the duration of the study and although we did not record grazing intensity yearly, we systematically surveyed all pastures twice a season in 2016-2018 to characterize the structure and cover conditions at our sites (TableA1.1; see Data collection). In 2018, one of our Montana study pastures had to be partially shifted because of a severe unscheduled burn the previous fall.

\section{Data collection}

Nesting success

We located and monitored nests (Table 1) of Baird's and Grasshopper Sparrows from May 24th to August 7th, 2015-2018. To maximize focal species sample-size, we located nests using rope-dragging and systematic walking (Winter et al. 2003), behavioral observation (Martin and Geupel 1993), and opportunistic discovery while traversing plots during other 
research activities (e.g., telemetry, vegetation surveys). Because birds are most active early in the morning, and there is evidence that grassland birds are most likely to be on the nest from sunrise to 0900 (see Davis and Holmes 2012, Kirkham and Davis 2013), we conducted our nest searching efforts primarily during this period. We did not conduct rope-drag surveys when temperatures were less than $10^{\circ} \mathrm{C}$, when grass was excessively wet (enough to soak boots and clothing), or during active precipitation.

Table 1. Sampling effort for nests located, adults fitted with VHF radio-tags, and fledglings fitted with VHF radio-tags for Baird's Sparrow and Grasshopper Sparrow at demographic study sites in western North Dakota (ND), and northeastern Montana (MT), 2015-2018.

\begin{tabular}{lccccc}
\hline \hline Year & Site & Species & Nests & $\begin{array}{c}\text { Adults } \\
\text { tagged }\end{array}$ & $\begin{array}{c}\text { Fledglings } \\
\text { tagged }\end{array}$ \\
\hline 2015 & ND & Baird's Sparrow & 15 & 24 & - \\
& & Grasshopper Sparrow & 29 & 29 & - \\
2016 & \multirow{2}{*}{ ND } & Baird's Sparrow & 10 & 29 & 6 \\
& \multirow{4}{*}{ MT } & Grasshopper Sparrow & 62 & 31 & 18 \\
& \multirow{4}{*}{ ND } & Baird's Sparrow & 27 & 35 & 16 \\
& \multirow{4}{*}{ MT } & Grasshopper Sparrow & 6 & 20 & - \\
& \multirow{4}{*}{ ND18 } & Baird's Sparrow & 14 & 33 & 12 \\
& \multirow{2}{*}{ ND } & Grasshopper Sparrow & 35 & 40 & 1 \\
& \multirow{4}{*}{ MT } & Baird's Sparrow & 39 & 46 & 30 \\
& \multirow{4}{*}{ Gll yearshopper Sparrow } & 10 & 29 & 10 \\
& All sites & Baird's Sparrow & 6 & - & 1 \\
& & Grasshopper Sparrow & 51 & - & 27 \\
& & Baird's Sparrow & 41 & - & 29 \\
& & Grasshopper Sparrow & 16 & - & 6 \\
& & Baird's Sparrow & 152 & 167 & 94 \\
& & Grasshopper Sparrow & 209 & 149 & 62 \\
& & All species & 361 & 316 & 156 \\
\hline
\end{tabular}

Upon locating nests, we marked the location with two pin-flags, one $5 \mathrm{~m}$ to the north, and the other $5 \mathrm{~m}$ to the south; we did not place any markers immediately near nest openings to avoid attracting predators directly to nests. We visited nests every three days, with longer intervals occasionally (e.g., five days) in cases of poor weather. We used Global Positioning System (GPS; etrex 10 and etrex 20; Garmin Ltd., Olathe, KS, USA) units and handdrawn microhabitat maps with compass bearings to relocate nest entrances during checks. We also took care to avoid creating trails by varying our approaches to the nest (Major 1990). To increase our ability to correctly assign nest fates, we visited nests more frequently (1-2 days) when they were near fledging age. Human visitation frequency does not appear to affect the nesting success of ground-nesting grassland birds (O'Grady et al. 1996, Pietz et al. 2012, Border et al. 2018), thus we felt this approach could improve the accuracy of our nesting success data with little risk. At each visit, we recorded and photographed nest contents, examined nests for evidence of predators or brood parasitism by Brown-headed Cowbirds (Molothrus ater), and aged nestlings based on physiological development (Jongsomjit et al. 2007, Ruth and Kitting 2018). To address nest fate uncertainty (Manolis et al. 2000), we implemented 15-minute fledgling searches during the final visit to every potentially successful nest (mean fledging age for the species; Davis 2003 and Jones et al. 2010). During these observation periods, we searched the nest area for fledglings and observed adults for feeding activity. These data helped us to confirm whether nests had fledged or been depredated during the late nestling stage when exact age at termination could not be known (Manolis et al. 2000). We found that the movements of both Baird's and Grasshopper Sparrow fledglings at our sites was extremely limited during this period (Fig. A2.1-2) reducing the possibility of conflating fledglings from neighboring territories (Streby and Andersen 2013a). We considered nests successful if they fledged at least one host young, failed if they did not, and unknown in cases where nestlings were potentially old enough to fledge, but we found no clear evidence of fledging or depredation (see Manolis et al. 2000).

\section{Adult survival.}

We captured and tracked adult male Baird's and Grasshopper Sparrows from May 14th to August 10th, 2015-2017 (Table 1). We chose to focus our capture efforts on males to avoid disrupting nesting females, as pilot data indicated that capture of nesting females triggered nest abandonment. To capture birds, we identified territorial individuals, set up 1-2 mobile mist-nets where we observed males perching and singing, and played audio-lure at the net location to draw birds in for capture. We conducted target-netting activities from sunrise to $1000 \mathrm{MST}$, but we did not target-net in temperatures less than $10^{\circ} \mathrm{C}$, during precipitation, or winds greater than $\sim 24 \mathrm{~km} / \mathrm{h}$. Following capture, we outfitted individuals with very high frequency (VHF) radio-transmitters (PicoPip Ag379; 0.42 g, 30-40-day battery-life; Lotek Wireless, Seattle, WA, USA) using an elastic leg-loop harness for attachment (Rappole and Tipton 1991). We weighed all birds prior to transmitter attachment $(\overline{\mathrm{x}}=18.1 \mathrm{~g}, \mathrm{SD}=1.1)$ to ensure that the transmitter weighed no more than $4 \%$ of the individual's total body mass. We also fitted all captured birds with a United States Geological Survey (USGS) federal aluminum band, and one or more plastic color bands, and collected standard morphometrics. We briefly observed birds for signs of adverse reaction to harness fit following release (e.g., hampered flight ability).

We tracked all tagged birds daily (sunrise to 1500 MST) using a receiver (Biotrack VHF Receiver; Lotek Wireless) and 3- or 5element folding Yagi antennae (Advanced Telemetry Systems, Isanti, MN, USA). During tracking, we took care to vary the time of day we tracked a given individual bird, and to circle a suspected bird location before flushing the bird, to avoid chasing it through the grass and influencing the recorded location. We recorded a single location per individual each day. We did not track birds in extreme weather conditions (e.g., lightening, heavy rain, excessive winds). After locating birds, we recorded their status (alive or dead) and their location using hand-held GPS units. We tracked birds until transmitters failed (failure was usually characterized by weak or intermittent signal prior to disappearance) or until signal suddenly disappeared (before the expected life of the transmitter). In the latter case, we searched the perimeter of the plot using a 5-element antenna for extended range, but we were rarely successful in relocating birds once we had lost the signal. It is likely these individuals emigrated, given the nomadic lifehistory of grassland birds. For example, breeding Grasshopper Sparrows are known disperse up to $9 \mathrm{~km}$ within season (Williams and Boyle 2018). However, we considered the fates of missing individuals unknown, as emigration could not be confirmed. We considered birds dead only when we found physical evidence of mortality (e.g., dead bird, blood on harness, transmitter with chew 
marks, pile of feathers, transmitter found buried, etc.). In cases where we found an undamaged, clean transmitter and harness, we assumed it had fallen off due to loose fit, or that the bird had been able to remove it by pulling at the elastic with its bill. In some instances, individuals previously fitted with a transmitter were recaptured confirming that they were alive and had shed their harnesses. We were not able to assess the presence of negative transmitter effects in our study (Barron et al. 2010), as we did not have a control group for comparison. However, we seldom observed unusual behavior in tagged birds during our study. In most cases, individuals displayed good flight ability and resumed territorial behavior after release (e.g., perching and singing, interacting with other males).

\section{Post-fledging survival}

We monitored post-fledging survival in Baird's and Grasshopper Sparrows from June 15th to August 7th, 2016-2018 (Table 1). We tagged 1-2 nestlings per nest with VHF transmitters (PicoPip Ag337; 0.29 g, 20-30-day battery-life; Lotek Wireless), depending on the brood-size and individual weights, when nestlings were 7-8 days old. We chose this age to help minimize risk of force fledging (Berkeley et al. 2007), as our focal species typically fledge at 9-10 days old in the NGP (Davis 2003, Jones et al. 2010). We used the same leg-loop harness attachment as for adults, but with a slightly looser harness fit to allow for growth. We also weighed and applied federal metal bands to all nestlings prior to transmitter attachment $(\overline{\mathrm{x}}=13.6 \mathrm{~g}, \mathrm{SD}=1.3)$. We ensured that transmitters weighed no more than $3.0 \%$ of the individual's total body. In cases where greater than two individuals weighed enough to receive transmitters in a nest, we selected individuals to tag by placing all nestlings of adequate weight in a bird bag and drawing at random. After the birds fledged, we tracked tagged birds daily using the same protocols described for adults but with additional caution to avoid trampling young fledglings.

We considered fledglings dead if they were less than 10 days old when the signal was lost following Hovick et al. (2011), as our movement data (Fig. A2.1-2) suggested that fledglings were not capable of traveling a distance beyond our antenna range $(\sim 300-400 \mathrm{~m})$ from their previous location in a single day at this age. This pattern of limited movement by young fledglings is widely reported in grassland songbirds (Davis and Fisher 2009, Hovick et al. 2011, Small et al. 2015, Young et al. 2019). We therefore assumed they had been carried off by a predator or that the transmitter was damaged during a depredation event. We were not able to compare survival between tagged and untagged birds because of the difficulty involved in tracking untagged fledglings in a grassland environment. However, research on Henslow's Sparrow (Centronyx henslowii) fledglings suggests the negative effects of transmitters are negligible (Young et al. 2019). We also acknowledge that in tracking only individuals of sufficient weight to allow tagging under our permits, our survival estimates may have been biased. Finally, we could not confidently partition causes of mortality in fledglings, as individuals that died of exposure or starvation could also show signs of predation from scavenging activities.

\section{Vegetation surveys and weather data}

We characterized the vegetation composition at each nest location using a Daubenmire frame (Daubenmire 1959) centered around the nest to estimate percent cover of live grass, dead grass, forbs, bare ground, and litter. We also estimated the mean height of vegetation contained within the frame. Finally, we estimated visual obstruction (VOR) at the nest site from four cardinal directions using a Robel pole at a distance of $4 \mathrm{~m}$ and a height of $1 \mathrm{~m}$ (Robel et al. 1970). We selected this suite of variables because they are the most commonly assessed and influential vegetation covariates in studies of grassland birds (Fisher and Davis 2010). We conducted vegetation surveys at nest sites within three days of nest termination to best represent conditions at the nest while it was active. We also collected vegetation data at fledgling bird telemetry locations in 2017-2018. Because estimated bird locations were sometimes less precise than nest locations, we estimated percent cover and mean vegetation height over a 5-m radius area around the bird location. The cover types we estimated at these locations included the same categories recorded at nest sites, in addition to an estimate of non-native species cover. Finally, to document overall vegetation conditions in each pasture, in 2016-2018, we conducted 5-m radius vegetation cover surveys as well as VOR and height measurements, in a systematic 100-m grid across each pasture. We surveyed this grid twice during each of three seasons, once in May and June, and a second time in July and August, for a combined total of 3637 surveys. We sourced daily temperature and precipitation data from the North Dakota Agricultural Weather Network (Beach, ND station; https://ndawn.ndsu.nodak.edu/) and the National Weather Service Forecast Office (Opheim, MT station; https://w2.weather. gov/climate/index.php?wfo=ffc).

\section{Animal welfare protocols and permitting}

Our capture and nest monitoring activities were in accordance with Montana, Fish, Wildlife \& Parks (MTFWP) Institutional Animal Care and Use Committee (IACUC) protocol \#FWP02-2015. We were granted state collection permits by North Dakota Game and Fish, and MTFWP, as well as a federal banding permit by the USGS Breeding Bird Laboratory (BBL; \#22415).

\section{Analysis}

Nesting success

To analyze nesting success, we estimated daily survival (DSR) of nests using logistic exposure (Shaffer 2004); we performed the analysis in Program R (R Version 3.6.1; R Core Team 2020) using the lme4 package (Bates et al. 2015). Logistic exposure is a modified form of logistic regression that accounts for length of exposure in survival analyses while also providing a flexible modeling approach in which multiple continuous and categorical variables can be included (Shaffer 2004). We included nests with unknown fates in analysis, but truncated intervals to the date of last known activity (Manolis et al. 2000). We combined failures from depredation, abandonment, cowbird parasitism, weather, and unexplained causes in analysis. In cases of nest abandonment, we assigned failure either to the interval following the last known date of nest activity, or the interval in which an event suspected of causing the abandonment occurred (e.g., partial predation, extreme weather event). We excluded nests we thought had been abandoned because of research activity, such as capture of an adult, from analysis $(n=34)$; this occurred primarily in 2015 and 2016 when we experimented with tracking adult females. We extrapolated DSR estimates produced with logistic exposure over a period approximating the length of a complete nesting cycle in 
each species (21 days for Baird's Sparrow and Grasshopper Sparrow; Davis 2003, Jones et al. 2010) to calculate the cumulative probability of nesting success.

We modeled the influence of environmental variables on nesting success with covariates for year (2015-2018), date (days from May $1^{\text {st }}$ ), daily precipitation, average precipitation over the previous week to observation date (hereafter weekly precipitation), daily minimum temperature, daily maximum temperature, and daily average temperature. We intended that weekly precipitation would capture effects of drought when present, while daily precipitation could reflect severe weather events as well. We averaged continuous, temporally explicit variables over intervals to best represent conditions during the exposure period being evaluated (see Shaffer 2004). We did not include lagged bio-year climate effects (i.e., effect of previous year's climate conditions) because we expected that any strong annual trends would be subsumed by year effects. Finally, we modeled a full suite of nest-site vegetation covariates including cover of live grass, dead grass, forbs, litter, bare ground, total grass, total vegetation, mean vegetation height and VOR.

We centered and standardized all continuous variables by subtracting the mean and dividing by the standard deviation to make parameter estimates directly comparable (Schielzeth 2010). We tested for correlation among all continuous variables using Pearson's correlation coefficient and did not include variables in the same model if $r>0.4$. We selected this threshold because it has been demonstrated that even low levels of collinearity can bias parameter estimates in multiple regression (Graham 2003). We constructed our models in a two-step process. First, to select among correlated variables to include in full analysis, and to compare linear and polynomial terms for continuous variables, we compared global models (consisting of non-correlated variables) with interchanged terms of interest (e.g., one global model with only linear date, one with linear and quadratic date). We tested all continuous predictors for both linear and quadratic effects. We used an information theoretic approach to model selection, selecting the model with the lowest $\mathrm{AIC}_{c}$ value (Burnham and Anderson 2002). Because site and year were conflated in our study (e.g., in 2015, data were only collected at the North Dakota site, and only in one pasture), we could not include both variables in global models, thus we chose to include year because it was of more interest to our study questions. However, we compared a univariate model with site to a constant survival model and found that, in both species, site models were indistinguishable from the null model by absolute distance (Baird's Sparrow: $\triangle \mathrm{AIC}_{c}=2.00$; Grasshopper Sparrow: $\triangle \mathrm{AIC}_{c}=$ 1.02). Following variable selection, we compared all model subsets (including a null constant survival model) evaluating the strength of each model using $\triangle \mathrm{AIC}_{c}$ and $\mathrm{AIC}_{c}$ weight $\left(w_{i}\right)$. We used a conservative threshold of $\Delta \mathrm{AIC}_{c}<2$ to determine top models in our comparisons (Burnham et al. 2011). To address modelselection uncertainty, we used the MuMin package (Barton 2020) to average predictions from a full suite of models (with $95 \%$ confidence intervals). However, because model-averaging has been criticized as a valid means of parameter estimation (Cade 2015), we report parameter estimates ( $\beta$ ) with standard errors (SE) and $85 \%$ confidence intervals (see Arnold 2010) from only the top model that each variable appeared in. To avoid the use of variable weights and model-averaged confidence intervals in detecting uninformative parameters (Cade 2015), we considered all variables appearing in the top model set to be informative, but only if $85 \%$ confidence intervals did not overlap zero in any top model. This procedure allowed us to filter out uninformative parameters in competitive models (Arnold 2010). We only discuss results and report estimates for variables that fit these criteria. Additionally, if the constant survival model appeared in the top model set, we took this as a lack of evidence for any effect of variables modeled for that species. Because the unit of analysis is the number of intervals in logistic exposure, not the number of nests (Shaffer 2004), we report interval sample-size in all modeling tables.

\section{Adult and post-fledging survival}

We used the same logistic exposure and information theoretic modeling approach described for nesting success to evaluate adult and post-fledging survival. Logistic exposure can be used to estimate survival similarly to nesting success (see Streby and Andersen 2013b), and in our case, it had several advantages. First, because the unit of analyses is the exposure interval and not the individual, we were able to include data from individuals with unknown fates in analysis by truncating encounter histories. Second, for the same reason, inability to disentangle permanent emigration from mortality in individuals did not directly influence our estimates (Lebreton et al. 1992). Third, we were not restricted to fixed re-sighting intervals and therefore could accommodate cases where individuals were tagged or re-sighted asynchronously. For adults, we extrapolated DSR estimates produced with logistic exposure over a 90-day period to estimate the cumulative probability of an individual surviving the breeding season under given conditions. For fledglings, we used a 20-day period; the exact age of independence is not known for either of our focal species, but a study of a similar species, Henslow's Sparrow, reported independence between 19-21 days post-fledge (Young et al. 2019). Additionally, a 20-day monitoring period was consistent both with the battery life of fledgling transmitters, and our observations of individuals in the field by this age (e.g., capable of strong flight, no longer observed being fed by parents).

We modeled the same temporal and climate variables described for nesting success for both adults and fledglings. For fledglings, we also modeled the effect of days post-fledge, and vegetation cover. Because vegetation data were only collected at fledgling bird locations in 2017-2018, we conducted two separate analyses of post-fledging survival to make use of the full sample, but also examine effects of vegetation. The first analysis included the full dataset and included all variables described above. The second analysis included only the 2017-2018 data and modeled all these variables in addition to a suite of vegetation variables including the previously described cover types (see Vegetation surveys and weather data), extent of non-native vegetation, and vegetation height. Because we did not collect vegetation data at adult bird locations in all years, we were not able to include these variables in the adult analysis. As with nesting success, we could not include variables for year and site in the same global models. However, we evaluated the effect of site in preliminary analysis and found that the site model was not distinguishable from the constant survival model in either species for adults (Baird's Sparrow: $\triangle \mathrm{AIC}_{c}$ $=1.76$; Grasshopper Sparrow: $\triangle \mathrm{AIC}_{c}=1.93$ ) or fledglings (Baird's Sparrow: $\Delta \mathrm{AIC}_{c}=2.00$; Grasshopper Sparrow: $\left.\Delta \mathrm{AIC}_{c}=0.48\right)$. 
Table 2. Number of estimated parameters (K), log likelihoods, AICc scores, $\triangle \mathrm{AICc}$, and model weights (Wi) for top models $(\triangle \mathrm{AICc}<2)$ explaining nesting success of Baird's Sparrows in western North Dakota $(2015-2018)$ and northeastern Montana (2016-2018). Sample size is given in exposure intervals.

\begin{tabular}{|c|c|c|c|c|c|}
\hline Model & $\mathrm{K}$ & LogLik & $\mathrm{AIC}$ & $\triangle \mathrm{AIC}$ & $\mathrm{W}_{i}$ \\
\hline \multicolumn{6}{|l|}{ Baird's Sparrow $(n=615)^{\dagger}$} \\
\hline Year + Date + Prcp + VOR & 7 & -217.02 & 448.22 & 0.00 & 0.03 \\
\hline Year + Date + VOR & 6 & -218.07 & 448.28 & 0.06 & 0.03 \\
\hline Date + Prcp & 3 & -221.16 & 448.36 & 0.14 & 0.02 \\
\hline Year + Date + Prcp + VOR + Litr & 8 & -216.07 & 448.38 & 0.16 & 0.02 \\
\hline Year + Date + VOR + Litr & 7 & -217.13 & 448.44 & 0.23 & 0.02 \\
\hline Year + Date + Prcp & 6 & -218.60 & 449.34 & 1.13 & 0.01 \\
\hline Date & 2 & -222.71 & 449.43 & 1.22 & 0.01 \\
\hline Year + Date & 5 & -219.76 & 449.63 & 1.41 & 0.01 \\
\hline Date + Prcp + Bare & 4 & -220.80 & 449.66 & 1.44 & 0.01 \\
\hline Year + Date + Prcp + VOR + Forb & 8 & -216.73 & 449.69 & 1.48 & 0.01 \\
\hline Year + Date + VOR + Live & 7 & -217.76 & 449.71 & 1.49 & 0.01 \\
\hline Year + Date + Prcp + VOR + Live & 8 & -216.76 & 449.76 & 1.55 & 0.01 \\
\hline Year + Date + VOR + Forb & 7 & -217.81 & 449.80 & 1.59 & 0.01 \\
\hline Year + Stage + Date + Prcp + VOR & 8 & -216.84 & 449.91 & 1.70 & 0.01 \\
\hline Year + Date + Prcp + VOR + Forb + Litr & 9 & -215.87 & 450.03 & 1.82 & 0.01 \\
\hline Year + Stage + Date + VOR & 7 & -217.93 & 450.05 & 1.83 & 0.01 \\
\hline Stage + Date + Prcp & 4 & -221.00 & 450.07 & 1.86 & 0.01 \\
\hline Year + Stage + Date + Prcp + VOR + Litr & 9 & -215.90 & 450.09 & 1.88 & 0.01 \\
\hline Year + Date + VOR + Forb + Litr & 8 & -216.94 & 450.12 & 1.91 & 0.01 \\
\hline Year + Date + VOR + Bare + Litr & 8 & -216.98 & 450.20 & 1.99 & 0.01 \\
\hline Year + Date + Prcp + VOR + Bare + Litr & 9 & -215.95 & 450.20 & 1.99 & 0.01 \\
\hline
\end{tabular}

\section{RESULTS}

During the study years, our North Dakota site received an average daily precipitation of $0.14 \mathrm{~cm}(\mathrm{SD}=0.42)$ and had an average daily temperature of $18.5^{\circ} \mathrm{C}(\mathrm{SD}=4.9)$ in the months of MayAugust. This site experienced moderate drought conditions (11-20th percentiles) in 2015 and abnormally dry conditions (21-30th percentiles) in 2016-2018 (United States Drought Monitor; https://droughtmonitor.unl.edu/About/WhatistheUSDM. aspx). Our Montana site received an average daily precipitation of $0.21 \mathrm{~cm}(\mathrm{SD}=0.56)$ and had an average daily temperature of $16.1^{\circ} \mathrm{C}(\mathrm{SD}=5.0)$. Mean vegetation ranges over the course of the study across the four pastures were as follows: visual obstruction reading (VOR; $3.5-10.5 \mathrm{~cm})$; vegetation height (16-25 $\mathrm{cm})$; total vegetation cover $(62-91 \%)$; grass cover $(48-77 \%)$; forb cover $(8-19 \%)$; shrub cover $(0-3 \%)$; bare ground cover $(6-35 \%)$; litter cover (3-19\%). The full site vegetation data can be found in TableA1.1.

\section{Nesting success}

We located and monitored nests of 152 Baird's Sparrows and 209 Grasshopper Sparrows. Combining data across sites and years, peak nest-initiation (back calculated from hatch date and nestling ages) for Baird's Sparrow (Fig. A3.1A) occurred on June $1^{\text {st }}$ (range: May $18^{\text {th }}-$ July $17^{\text {th }}$ ) while Grasshopper Sparrow (Fig. A3.1B) initiations were more diffuse and displayed a less distinct peak in mid-June (range: May $18^{\text {th }}-$ July $17^{\text {th }}$ ). Average clutchsizes were 4.2 $(\mathrm{SD}=0.83)$ for Baird's sparrow and 4.2 $(\mathrm{SD}=0.86)$ for Grasshopper sparrow. Brood parasitism by Brown-headed Cowbird was uncommon at our sites ( $2 \%$ of all nests monitored). Predation was the greatest cause of nest failure overall and accounted for $89 \%$ of total nest failures. Of all nests monitored, $92 \%$ of Baird's Sparrow nests and $89 \%$ of Grasshopper Sparrow nests had known fates.

\section{Baird's Sparrow}

Modeled DSR and cumulative survival were 95\% (CI: 89 to 98 ) and $37 \%$ (CI: 14 to 61 ) respectively under average conditions (covariates set to mean values). Success did not vary statistically among years (Fig. 2A). Covariates appearing in the top model set included year, nest stage, date, daily precipitation, visual obstruction reading (VOR), live grass cover, forb cover, bare ground cover, and litter cover (Table 2$)$. However, only date $(\beta$ $=-0.43, S E=0.15, \mathrm{CI}:-0.66$ to -0.20$)$ and VOR $(\beta=0.28, S E=$ 0.16 , CI: 0.05 to 0.52 ) had confidence intervals that never overlapped zero across top models. DSR for Baird's Sparrow declined as the season progressed (Fig.3A) and date had the strongest influence on nesting success in the species, appearing in all top models (Table 2) and having the largest effect size. Additional variation was explained by VOR, which had a moderate positive effect on DSR (Fig. 3B).

\section{Grasshopper Sparrow}

Modeled DSR and cumulative nesting success were 91\% (CI: 87 to 95 ) and $16 \%$ (CI: 5 to 33 ), respectively, and showed little annual variation (Fig. 2A). Nesting success in Grasshopper Sparrow was not influenced by any of the variables we modeled, as the constant survival model $\left(\triangle \mathrm{AIC}_{c}=1.27\right)$ was in the top model set (Table 3$)$ and $85 \%$ confidence intervals overlapped zero for all variables modeled. 
Table 3. Number of estimated parameters (K), log likelihoods, AICc scores, $\triangle \mathrm{AICc}$, and model weights (Wi) for top models $(\triangle \mathrm{AICc}<2)$ explaining nesting success of Grasshopper Sparrows in western North Dakota $(2015-2018)$ and northeastern Montana (2016-2018). Sample size is given in exposure intervals.

\begin{tabular}{|c|c|c|c|c|c|}
\hline Model & $\mathrm{K}$ & LogLik & $\mathrm{AIC}_{\mathrm{c}}$ & $\Delta \mathrm{AIC}_{\mathrm{c}}$ & $\mathrm{W}_{\mathrm{i}}$ \\
\hline \multicolumn{6}{|c|}{ Grasshopper Sparrow $(n=644)$} \\
\hline Bare & 2 & -326.05 & 656.11 & 0.00 & 0.01 \\
\hline Hght + Bare & 3 & -325.13 & 656.30 & 0.19 & 0.01 \\
\hline Hght & 2 & -326.34 & 656.70 & 0.59 & 0.01 \\
\hline Hght + VOR + Bare & 4 & -324.45 & 656.96 & 0.84 & 0.01 \\
\hline Date + Bare & 3 & -325.52 & 657.08 & 0.97 & 0.01 \\
\hline Date + Hght + Bare & 4 & -324.56 & 657.19 & 1.07 & 0.01 \\
\hline Hght + Litr & 3 & -325.67 & 657.38 & 1.26 & 0.01 \\
\hline Constant survival(null) & 1 & -327.69 & 657.39 & 1.27 & 0.01 \\
\hline Hght + Litr + Bare & 4 & -324.74 & 657.53 & 1.42 & 0.01 \\
\hline VOR + Bare & 3 & -325.77 & 657.58 & 1.46 & 0.01 \\
\hline Stage + Bare & 3 & -325.79 & 657.62 & 1.51 & 0.01 \\
\hline Live + Bare & 3 & -325.81 & 657.65 & 1.54 & 0.01 \\
\hline Prcp + Bare & 3 & -325.86 & 657.75 & 1.63 & 0.01 \\
\hline Stage + Hght + Bare & 4 & -324.87 & 657.79 & 1.68 & 0.01 \\
\hline Bare + Litr & 3 & -325.90 & 657.84 & 1.72 & 0.01 \\
\hline Year + Hght + Litr & 6 & -322.86 & 657.85 & 1.74 & 0.01 \\
\hline VOR + Hght & 3 & -325.95 & 657.94 & 1.82 & 0.01 \\
\hline VOR + Hght + Bare + Litr & 5 & -323.95 & 658.00 & 1.89 & 0.00 \\
\hline Forb + Bare & 3 & -325.99 & 658.03 & 1.91 & 0.00 \\
\hline Date + VOR + Hght + Bare & 5 & -323.97 & 658.03 & 1.92 & 0.00 \\
\hline Stage + Date + Bare & 4 & -325.00 & 658.06 & 1.95 & 0.00 \\
\hline Prcp + Hght + Bare & 4 & -325.00 & 658.06 & 1.95 & 0.00 \\
\hline
\end{tabular}

Bare $=\%$ bare ground, Date $=$ days from May $1^{\text {st }}$, Forb $=\%$ forb cover, Hght $=$ vegetation height, Litr $=\%$ litter cover, Live $=\%$ live vegetation, $\operatorname{Prcp}=$ daily precipitation, Stage $=$ nest stage, $\mathrm{VOR}=$ visual obstruction

Fig. 2. Logistic exposure estimates of Baird's Sparrow and Grasshopper Sparrow vital rates in western North Dakota (2015-2018) and northeastern Montana (2016-2018); cumulative nesting success (A), cumulative breeding-season adult survival (B), and cumulative post-fledging survival (C). Error bars denote $95 \%$ confidence intervals of model-averaged predicted values. Additional covariates are set to mean values to display rates by year.

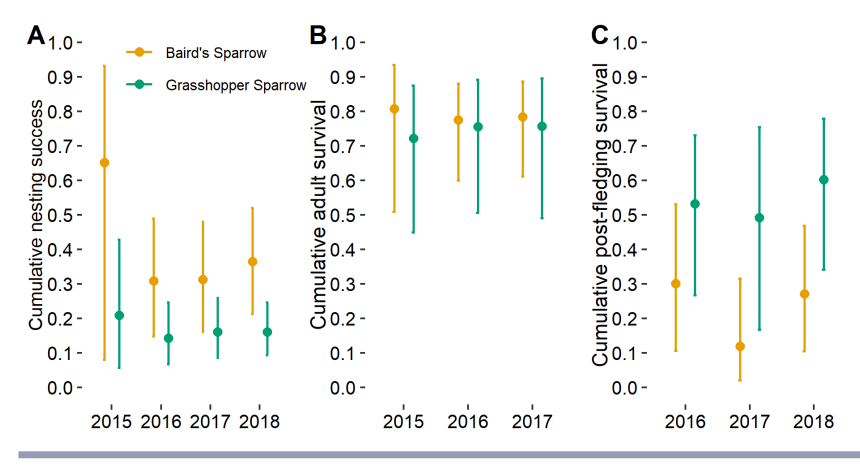

\section{Adult survival}

Over the course of the study, we tagged and monitored 167 adult male Baird's Sparrows and 149 adult male Grasshopper Sparrows. Of the individuals tagged, $49 \%$ of Baird's Sparrows and $27 \%$ of Grasshopper Sparrows had known fates, while the remaining individuals either left the study area, had a transmitter fail, or appear to have shed their transmitter. Although we did not
Fig. 3. Effect of date (A) and Visual Obstruction Reading (VOR) (B) on logistic exposure Daily Survival Rate (DSR) of nests of Baird's Sparrow breeding in western North Dakota (2015-2018) and northeastern Montana (2016-2018). Shading denotes $95 \%$ confidence intervals of model-averaged predicted values. Additional covariates are set to mean values to display effects of date and VOR.

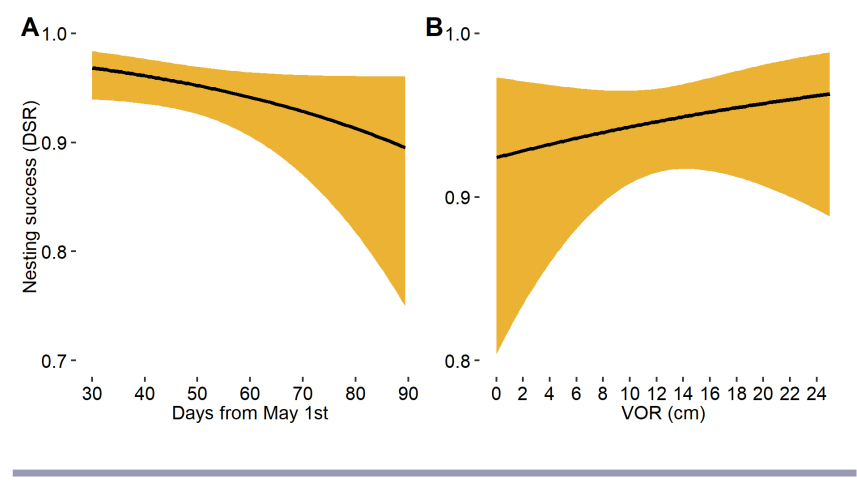

formally quantify mortality sources, we observed individuals that appeared to have died from weather exposure or illness with no visible injuries $(n=6)$, those that had lacerations or had been plucked and torn apart by predators $(\mathrm{n}=12)$, and in several instances we noted that transmitters were found near or inside ground squirrel (Spermophilina $\mathrm{sp}$.) burrows $(\mathrm{n}=3)$. Additionally, in two cases, transmitters were found in and near what were likely Short-eared Owl (Asio flameus) pellets. 


\section{Modelled survival estimates}

Logistic exposure analysis of survival produced DSR estimates of $99 \%$ (CI: 99 to 99 ) and 99\% (CI: 98 to 99) for male Baird's and Grasshopper Sparrows under average conditions. Cumulative breeding season survival estimates for the two species (Fig. 2B) were $78 \%$ (CI: 51 to 91 ) and 74\% (CI: 36 to 92 ) respectively. Survival was invariant among years, and none of the climate and time of season covariates we modeled explained variation in survival; the constant survival model was the top model for both species (Table 4).

Table 4. Number of estimated parameters (K), log likelihoods, AICc scores, $\triangle \mathrm{AICc}$, and model weights (Wi) for top models $(\triangle \mathrm{AICc}<2)$ explaining breeding season survival of adult male Baird's Sparrows and Grasshopper Sparrows in western North Dakota (2015-2018) and northeastern Montana (2016-2018). Sample sizes are given in exposure intervals.

\begin{tabular}{llllll}
\hline \hline Model & $\mathrm{K}$ & LogLik & $\mathrm{AIC}_{c}$ & $\Delta \mathrm{AIC}_{c}$ & $\mathrm{~W}_{\mathrm{i}}$ \\
\hline Baird's Sparrow $(n=3560)$ & & & & & \\
Constant survival(null) & 1 & -72.23 & 146.46 & 0.00 & 0.22 \\
Prcp(wk) & 2 & -71.56 & 147.13 & 0.67 & 0.16 \\
Date & 2 & -71.82 & 147.65 & 1.19 & 0.12 \\
Date + Prcp(wk) & 3 & -71.13 & 148.26 & 1.80 & 0.09 \\
Prcp & 2 & -72.16 & 148.33 & 1.87 & 0.09 \\
Grasshopper Sparrow $(n=2206)$ & & & & & \\
Constant survival(null) & 1 & -53.64 & 109.29 & 0.00 & 0.10 \\
Prcp & 2 & -52.74 & 109.49 & 0.20 & 0.09 \\
Prcp(wk) & 2 & -53.05 & 110.10 & 0.81 & 0.07 \\
Temp(max) & 2 & -53.07 & 110.15 & 0.86 & 0.06 \\
Date + Temp(max) & 3 & -52.15 & 110.32 & 1.02 & 0.06 \\
Date & 2 & -53.17 & 110.35 & 1.06 & 0.06 \\
Prcp + Prcp(wk) & 3 & -52.24 & 110.49 & 1.20 & 0.05 \\
Prcp + Temp(max) & 3 & -52.32 & 110.65 & 1.36 & 0.05 \\
Date + Prcp & 3 & -52.34 & 110.69 & 1.40 & 0.05 \\
Prcp(wk) + Temp(max) & 3 & -52.52 & 111.04 & 1.75 & 0.04 \\
Date + Prcp + Temp(max) & 4 & -51.61 & 111.23 & 1.94 & 0.04 \\
\hline Bare $\%$ bare ground, Date & &
\end{tabular}

Bare $=\%$ bare ground, Date $=$ days from May $1^{\text {st }}, \operatorname{Prcp}=$ daily precipitation, $\operatorname{Prcp}(w k)=$ weekly precip., $\operatorname{Temp}(\mathrm{mx})=\max$ temp.

\section{Post-fledging survival}

We tagged and monitored the survival of 94 fledgling Baird's Sparrows and 62 fledgling Grasshopper Sparrows over the duration of our study. Of these individuals, 95\% of Baird's Sparrows and $71 \%$ of Grasshopper Sparrows had known fates. The remaining birds were greater than 10 days old when their signals were lost and potentially had the flight capability to leave study pastures, but because they could also have been carried off by predators, their fates were unknown. As with adults, we did not formally attempt to determine the cause of mortality for fledglings. However, we observed fledglings of both species that had likely been depredated or scavenged $(n=40)$. In these cases, bodies were found injured and dismembered, or transmitters were recovered with blood, feathers, or chew marks. We also recorded instances where transmitters were found buried or in ground squirrel burrows $(n=8)$, and in two cases, transmitters were tracked after being consumed by Plains Garter Snakes (Thamnophis radix). We also noted many cases where no sign of predation could be found, and mortality was likely associated with starvation or exposure $(n=23)$.

\section{Baird's Sparrow}

DSR and cumulative survival for Baird's Sparrow fledglings under average conditions were $93 \%$ (CI: 89 to 96 ) and $25 \%$ (CI: 9 to 45 ), respectively, and varied little by year (Fig. 2C). Although year, daily and weekly precipitation, and minimum daily temperature appeared in top models for the species (Table 5), survival was primarily driven by a positive effect of age (Fig. 4A), the only variable with confidence intervals not overlapping zero. This effect was quadratic $(\beta=1.87, S E=0.26, \mathrm{CI}$ : 1.52 to $2.27 ; \beta$ $=-0.70, S E=0.17, \mathrm{CI}:-0.94$ to -0.44$)$. Analysis of 2017-2018 data only, including variables describing vegetation structure and composition (Table 6), revealed that survival of fledgling Baird's Sparrows also increased with vegetation height $(\beta=0.87, S E=$ 0.26 , CI: 0.50 to 1.26; Fig. $5 \mathrm{~A}$ ) and began to decline with $>50 \%$ non-native plant cover, fitting a quadratic effect $(\beta=-1.03, S E=$ 0.26 , CI: -1.65 to -0.58 ; Fig. $5 \mathrm{~B}$ ).

Fig. 4. Effects of age on logistic exposure Daily Survival Rate (DSR) of fledgling Baird's Sparrows (A) and fledgling Grasshopper Sparrows (B) in western North Dakota and northeastern Montana, 2016-2018. Shading denotes 95\% confidence intervals of model-averaged predicted values. Additional covariates are set to mean values to display effects of age.

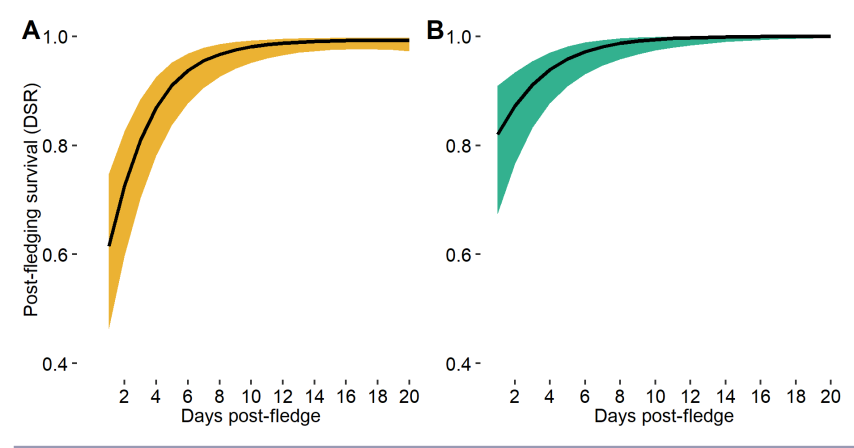

Fig. 5. Effects of vegetation height (A) and non-native plant cover (B) on logistic exposure Daily Survival Rate (DSR) of fledgling Baird's Sparrows in western North Dakota and northeastern Montana, 2017-2018. Shading denotes 95\% confidence intervals of model-averaged predicted values. Additional covariates are set to mean values to display effects of vegetation.

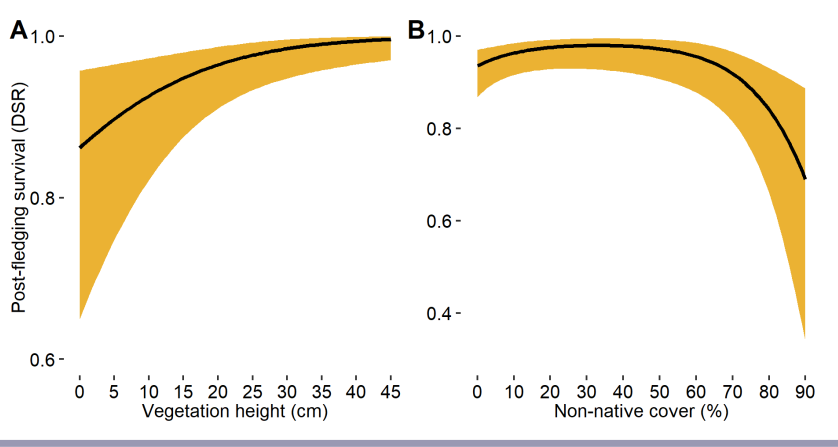


Table 5. Number of estimated parameters (K), log likelihoods, AICc scores, $\triangle \mathrm{AICc}$, and model weights (Wi) for top models $(\triangle \mathrm{AICc}<2)$ explaining post-fledging survival of Baird's Sparrows and Grasshopper Sparrows in western North Dakota and northeastern Montana, 2016-2018. Sample sizes are given in exposure intervals.

\begin{tabular}{|c|c|c|c|c|c|}
\hline Model & $\mathrm{K}$ & LogLik & $\mathrm{AIC}_{\mathrm{c}}$ & $\Delta \mathrm{AIC}_{\mathrm{c}}$ & $\mathrm{W}_{\mathrm{i}}$ \\
\hline \multicolumn{6}{|l|}{ Baird's Sparrow $(n=500)^{\dagger}$} \\
\hline Year + Age + Age $^{2}$ & 5 & -146.21 & 302.55 & 0.00 & 0.15 \\
\hline Year + Age $+\mathrm{Age}^{2}+\operatorname{Prcp}(w k)$ & 6 & -145.24 & 302.65 & 0.10 & 0.15 \\
\hline Year + Age $+\mathrm{Age}^{2}+\operatorname{Prcp}+\operatorname{Prcp}(w k)$ & 7 & -144.34 & 302.91 & 0.36 & 0.13 \\
\hline Year + Age $+\mathrm{Age}^{2}+$ Prcp & 6 & -145.71 & 303.58 & 1.03 & 0.09 \\
\hline Year + Age + Age $^{2}+\operatorname{Prcp}+\operatorname{Prcp}(w k)+$ Temp $(m n)$ & 8 & -143.97 & 304.23 & 1.68 & 0.07 \\
\hline Year + Age + Age $^{2}+\operatorname{Prcp}(w k)+$ Temp $(m n)$ & 7 & -145.01 & 304.26 & 1.71 & 0.07 \\
\hline Year + Age + Age $^{2}+$ Temp $(\mathrm{mn})$ & 6 & -146.08 & 304.32 & 1.77 & 0.06 \\
\hline Age $+\operatorname{Age}^{2}+\operatorname{Prcp}(w k)+\operatorname{Temp}(m n)$ & 5 & -147.12 & 304.36 & 1.81 & 0.06 \\
\hline Age + Age $^{2}+\operatorname{Prcp}+\operatorname{Prcp}(w k)+$ Temp $(m n)$ & 6 & -146.12 & 304.40 & 1.85 & 0.06 \\
\hline \multicolumn{6}{|l|}{ Grasshopper Sparrow $(n=543)^{*}$} \\
\hline Age $+\operatorname{Prcp}(w k)$ & 3 & -79.44 & 164.93 & 0.00 & 0.21 \\
\hline Age & 2 & -81.15 & 166.33 & 1.40 & 0.11 \\
\hline Year + Age & 4 & -79.18 & 166.43 & 1.50 & 0.10 \\
\hline Age $+\operatorname{Prcp}(w k)+\operatorname{Temp}(m n)$ & 4 & -79.23 & 166.54 & 1.61 & 0.09 \\
\hline Year + Age + Prcp $(w k)$ & 5 & -78.28 & 166.67 & 1.74 & 0.09 \\
\hline Age $+\operatorname{Prcp}+\operatorname{Prcp}(w k)$ & 4 & -79.42 & 166.91 & 1.98 & 0.08 \\
\hline
\end{tabular}

\section{Grasshopper Sparrow}

DSR and cumulative survival for Grasshopper Sparrow fledglings under average conditions were and 97\% (CI: 94 to 99) and 55\% (CI: 27 to 76) respectively, and survival was consistent among years (Fig. 2C). As in Baird's Sparrow, variables for year, precipitation, and temperature appeared in top models (Table 5), but only age was influential (Fig. 4B) and survival increased with days post-fledge $(\beta=2.74, \mathrm{SE}=0.65, \mathrm{CI}$ : 1.89 to 3.77$)$. Analysis of vegetation cover and survival (Table 6) indicated that postfledging Grasshopper Sparrow survival also declined with greater cover of dead grass $(\beta=-0.92, S E=0.25, \mathrm{CI}:-1.30$ to -0.56 ; Fig. $6)$.

Fig. 6. Effects of dead grass cover on logistic exposure Daily Survival Rate (DSR) of fledgling Grasshopper Sparrows in western North Dakota and northeastern Montana, 2017-2018. Shading denotes $95 \%$ confidence intervals of model-averaged predicted values. Additional covariates are set to mean values to display effects of dead grass.

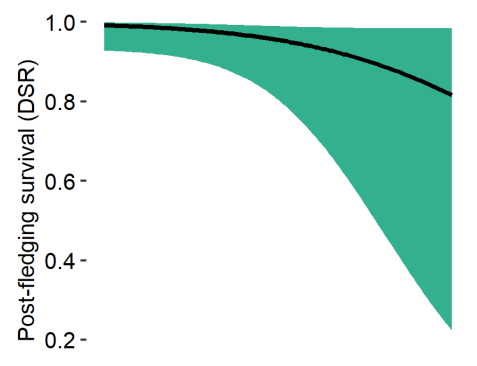

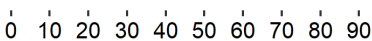
Dead grass cover (\%)

\section{DISCUSSION}

Examining multiple vital rates in populations of management interest can provide a broader view of species demographics and more accurately inform management activities. Our analysis of nesting success, breeding-season adult survival, and post-fledging survival in Baird's and Grasshopper Sparrows in the Northern Great Plains (NGP) revealed differences in response to environmental conditions among vital rates, as well as between species, highlighting the value of multi-stage monitoring in understanding species-habitat relationships. We found that mixed-grass prairie specialist Baird's Sparrow was generally more responsive to habitat conditions than the more generalist Grasshopper Sparrow. Baird's Sparrow responded to several environmental covariates in nesting success (time of season, vertical vegetation structure) and post-fledging survival (vegetation height, non-native vegetation cover) while Grasshopper Sparrow was only responsive to one environmental covariate (dead grass cover) across all rates estimated. Adult survival of both species was consistent and high relative to existing overwintering survival estimates for the two species, suggesting that adult survival during other parts of the annual cycle may be of greater importance. Finally, cumulative post-fledging survival of Baird's Sparrow was low relative to theoretical demographic thresholds (Cox et al. 2014) indicating that this vulnerable lifehistory stage is potentially important for the species.

\section{Drivers of vital rates}

We found that relationships between survival and environmental conditions varied by vital rate and species. Time of season was the strongest predictor of nesting success for Baird's Sparrow, which declined as the season progressed, an effect previously reported in the species (Davis 2005, Lusk and Koper 2013, Davis et al. 2016b) and in grassland birds generally (Zimmerman 1984, Grant et al. 2005, Davis et al. 2006, Grant and Shaffer 2012). This pattern may correspond to increases in predator abundance 
Table 6. Number of estimated parameters (K), log likelihoods, AICc scores, $\triangle \mathrm{AICc}$, and model weights (Wi) for top models $(\triangle \mathrm{AICc}<2)$ explaining post-fledging survival of Baird's Sparrows and Grasshopper Sparrows in western North Dakota and northeastern Montana, 2017-2018. Sample sizes are given in exposure intervals.

\begin{tabular}{|c|c|c|c|c|c|}
\hline Model & $\mathrm{K}$ & LogLik & $\mathrm{AIC}_{\mathrm{c}}$ & $\Delta \mathrm{AIC}_{\mathrm{c}}$ & $\mathrm{W}_{\mathrm{i}}$ \\
\hline \multicolumn{6}{|l|}{$\overline{\text { Baird's Sparrow }(n=317)^{\dagger}}$} \\
\hline Age $+\operatorname{Age}^{2}+$ Temp $(m n)+H g h t+E x t c+\operatorname{Extc}^{2}$ & 7 & -80.66 & 175.68 & 0.00 & 0.06 \\
\hline Year + Age $^{2}+$ Age + Temp $(m n)+$ Hght + Extc + Extc $^{2}$ & 8 & -79.76 & 175.99 & 0.31 & 0.05 \\
\hline $\mathrm{Age}+\mathrm{Age}^{2}+\mathrm{Temp}(\mathrm{mn})+\mathrm{Hght}+$ Forb + Extc + Extc $^{2}$ & 8 & -80.17 & 176.80 & 1.13 & 0.03 \\
\hline Year $+\mathrm{Age}^{2}+\mathrm{Age}+\mathrm{Hght}+\mathrm{Extc}+\mathrm{Extc}^{2}$ & 7 & -81.41 & 177.18 & 1.50 & 0.03 \\
\hline Year + Age $^{2}+$ Age + Temp $(\mathrm{mn})+\mathrm{Hght}+\mathrm{Live}+\mathrm{Extc}+\mathrm{Extc}^{2}$ & 9 & -79.30 & 177.20 & 1.52 & 0.03 \\
\hline $\mathrm{Age}+\mathrm{Age}^{2}+\operatorname{Prcp}+\mathrm{Temp}(\mathrm{mn})+\mathrm{Hght}+\mathrm{Extc}+\mathrm{Extc}^{2}$ & 8 & -80.47 & 177.41 & 1.73 & 0.03 \\
\hline Year + Age + Age $^{2}+$ Temp $(m n)+$ Hght + Forb + Extc + Extc $^{2}$ & 9 & -79.41 & 177.41 & 1.74 & 0.03 \\
\hline $\mathrm{Age}+\mathrm{Age}^{2}+$ Prwk + Temp $(\mathrm{mn})+\mathrm{Hght}+\mathrm{Extc}+\mathrm{Extc}^{2}$ & 8 & -80.48 & 177.43 & 1.76 & 0.02 \\
\hline Year + Age + Age $^{2}+\operatorname{Prcp}+$ Temp $(\mathrm{mn})+\mathrm{Hght}+$ Extc + Extc $^{2}$ & 9 & -79.49 & 177.56 & 1.88 & 0.02 \\
\hline Age $+\mathrm{Age}^{2}+$ Temp $(\mathrm{mn})+\mathrm{Hght}+\mathrm{Live}+$ Extc + Extc $^{2}$ & 8 & -80.56 & 177.59 & 1.91 & 0.02 \\
\hline $\mathrm{Age}+\mathrm{Age}^{2}+\mathrm{Temp}(\mathrm{mn})+\mathrm{Hght}+\mathrm{Litr}+\mathrm{Extc}+\mathrm{Extc}^{2}$ & 8 & -80.59 & 177.64 & 1.97 & 0.02 \\
\hline \multicolumn{6}{|l|}{ Grasshopper Sparrow $(n=309)^{*}$} \\
\hline Age + Dead & 3 & -34.04 & 74.15 & 0.00 & 0.04 \\
\hline Age $+\mathrm{Hght}+\mathrm{Hght}^{2}+$ Dead & 5 & -32.18 & 74.56 & 0.40 & 0.03 \\
\hline Age + Hght $+\mathrm{Hght}^{2}+$ Dead + Litr & 6 & -31.23 & 74.75 & 0.59 & 0.03 \\
\hline Age + Dead + Litr & 4 & -33.31 & 74.76 & 0.60 & 0.03 \\
\hline Age + Dead + Grass & 4 & -33.69 & 75.51 & 1.36 & 0.02 \\
\hline Age + Dead + Temp $(m n)$ & 4 & -33.72 & 75.58 & 1.43 & 0.02 \\
\hline Age + Dead + Prcp & 4 & -33.73 & 75.58 & 1.43 & 0.02 \\
\hline Year + Age + Dead & 4 & -33.92 & 75.96 & 1.81 & 0.02 \\
\hline Age + Prcp + Hght $+\mathrm{Hght}^{2}+$ Dead & 6 & -31.91 & 76.10 & 1.95 & 0.02 \\
\hline \multicolumn{6}{|c|}{$\begin{array}{l}\text { AIC }{ }_{\mathrm{c} \text { constant }}=254.88 \\
\mathrm{AIC} \mathrm{c}_{\mathrm{c} \text { constant }}=94.88 \\
\text { Age }=\text { days post-fledge, Dead }=\% \text { dead vegetation, Exotic }=\% \text { exotic cover, Forb }=\% \text { forb cover }, \text { Grass }=\% \text { grass cover, Hght }= \\
\text { vegetation height, Liter }=\% \text { litter cover, Live }=\% \text { live vegetation, Prcp }=\text { daily precipitation, Temp }(\mathrm{mn})=\text { min temp., Year }=\text { study } \\
\text { year }\end{array}$} \\
\hline
\end{tabular}

following early season reproduction (Grant et al. 2005) or increased activity of exothermic predators coupled with warming conditions and longer days through the progression of the breeding season (Burhans et al. 2002). Nests of grassland songbirds in the NGP are subject to predation pressure from a diverse array of nest predators including small mammals, large mammals, snakes, and avian predators (Pietz et al. 2012, BernathPlaisted and Koper 2016). Thus, earlier nest initiation on the breeding grounds may be adaptive to increase nesting success by avoiding predation pressure later in the season (Grant et al. 2005). Alternatively, this effect could have been driven by higher quality of early-arriving individuals (Wheelwright and Schultz 1994, Verhulst and Nilsson 2008). Nesting success of Baird's Sparrow was also partially driven by a positive effect of VOR (visual obstruction reading) matching the species' preference for both habitat and nest-site selection (Dieni and Jones 2003, Davis 2005, Lipsey and Naugle 2017) and further supporting the hypothesis that increased cover can provide concealment from nest predators (Winter 1999, Fondell and Ball 2004, Davis 2005, Klug et al. 2010).

Survival in fledglings of both species was strongly driven by age, with most mortalities concentrated within the first five days postfledge. This pattern is common in fledgling songbirds (Cox et al. 2014) and specifically in grassland birds (Kershner et al. 2004, Fisher and Davis 2011, Hovick et al. 2011, Young et al. 2019). A likely explanation for this pattern is increased mobility with age; fledgling birds may be better able to evade predators as they develop sustained flight. Age may also act as a proxy for body condition, which can also be an important predictor of survival in fledgling grassland birds (Adams et al. 2006, Suedkamp Wells et al. 2007, Jones et al. 2017). Thus, because ethical and permitting limitations prevented us from placing transmitters on individuals below a certain weight threshold, it is possible that our rates overestimate post-fledging survival to some extent. Conversely, it is also possible that transmitters themselves reduced fledgling survival creating a negative bias (Barron et al. 2010) though there is some evidence that transmitters have little effect on fledgling grassland birds (Young et al. 2019).

Post-fledging survival in our study was also influenced by vegetation structure and composition. In Baird's Sparrow, survival increased with greater vegetation height. This finding is consistent with other studies of post-fledging survival in grassland bird species and supports the hypothesis that vegetation cover may provide a refuge from predators during a critical lifehistory period of high-mortality (Jones and Bock 2005, Berkeley et al. 2007, Small et al. 2015, Jones et al. 2017). Predation is typically identified as the largest source of mortality in studies of post-fledging survival in grassland songbirds (Adams et al. 2001, Kershner et al. 2004, Suedkamp Wells et al. 2007, Hovick et al. 2011). Though shading and shelter from severe weather are also plausible benefits of taller vegetation, these mechanisms seem less likely in our study as we found no effect of climate conditions on the post-fledging survival of either species. Post-fledging survival in Grasshopper Sparrow responded negatively to increased cover of dead grass, though the mechanism underlying this effect is less clear. It is possible that stiff dead grass impeded movement of fledglings, or that it provided fewer food resources relative to live vegetation. Finally, we also found that survival of fledgling Baird's 
Sparrow was negatively affected by cover of non-native plant species. Non-native plants have been linked to reduced food availability in grassland systems (Flanders et al. 2006, Hickman et al. 2006) and although fledglings were still being fed by parents during the monitoring period in our study, a reduction in local food resources could have hampered provisioning efficiency of adults. Negative effects of non-native vegetation on vital rates have been reported for several grassland-obligate songbirds in the Great Plains (Lloyd and Martin 2005, Fisher and Davis 2011, Ludlow et al. 2015, Davis et al. 2016b), but more mechanistic studies are needed to understand and mitigate these apparent deleterious effects.

\section{Species differences}

Generally, we found many more relationships between vital rates and the environmental covariates tested for Baird's Sparrow than for Grasshopper Sparrow. The only influential covariates we found for Grasshopper Sparrow affected fledgling survival, where survival declined with dead grass cover and increased with fledgling age. There was no effect of time of season on the nesting success of Grasshopper Sparrow (as there was for Baird's), a surprising finding as nests of both Baird's and Grasshopper Sparrows are likely preyed upon by a similar predator community. Given the similarity in nest structure and habitat preference between the two species, it is possible that heightened predation at Grasshopper Sparrow nests was the result of behavioral differences between the two species. We observed that Grasshopper Sparrows were often more conspicuous at the nest site, perching and chipping when observers approached the nest area, and thus perhaps more liklely to attract predators. Conversly, Baird's Sparrows were often quiet or not visible during nest checks, particularly early in the nesting cycle. Once again, unlike Baird's Sparrow, success of Grasshopper Sparrow nests was also unaffected by vegetation height. One explanation for this discrepancy could be that, in the NGP, although general habitat preferences of Baird's Sparrow and Grasshopper Sparrow are similar (Lipsey and Naugle 2017), Baird's Sparrow has been shown to select more strongly for increased vegetation height at the nest site than Grasshopper Sparrow (Dieni and Jones 2003). We observed this difference in nest-site selection in our study as well, though the difference was marginal (Guido 2020).

Interestingly, lack of response to vegetation characteristics in Grasshopper Sparrow relative to Baird's Sparrow was also apparent in the post-fledging phase. We did not observe a negative effect of non-native cover in survival of fledgling Grasshopper Sparrows, as we did in Baird's Sparrow. It is possible that feeding niches of the two species are subtly different, affecting their ability to exploit non-native food resources. For example, a study of the overwintering diet in Baird's Sparrow and Grasshopper Sparrow found that the two species had different seed preferences and food handling times as a result of differing bill morphologies (Titulaer et al. 2018). More broadly, inconsistent response of vital rates to environmental conditions between the two species could be explained in part by divergent life-history strategies. Baird's Sparrow exhibits more of the common specialist characteristics of the two species, occupying a smaller geographic range (Fig. 1; BirdLife International 2016), less varied habitat-use (Green et al. 2002, Vickery et al. 1996), and lower population numbers (Partners in Flight 2020). It may be that Baird's Sparrows are simply more sensitive to environmental conditions than Grasshopper Sparrows as a consequence of inherent life history differences. Specialists species are highly successful when operating within ideal habitat conditions, but they have a limited ability adapt to sub-optimal or marginal environments (Correll et al. 2019). For example, it is possible that Baird's sparrow was less successful at foraging in habitat that is partially degraded by non-native plant species than Grasshopper Sparrow, resulting in higher fledging mortality for Baird's sparrow. Conversely, Baird's sparrow could be better adapted to select highly-concealed nest sites in mixed-grass prairie than Grasshopper Sparrow, which uses a shorter vegetation structure in many parts of its range (Vickery 1996), perhaps explaining the lack of positive response to vertical structure in Grasshopper sparrow. Regardless of mechanism, inconsistent effects of vegetation structure on vital rates are frequently reported in mixed-grass prairie songbird communities (Davis 2005, Koper and Schmiegelow 2007, Kerns et al. 2010, Lusk and Koper 2013). This variation in reponse to structure among species reflects the unique microhabitat needs of grassland songbirds and serves as a reminder that grassland songbird species can be poor management surrogates for one another (Davis 2005, Derner et al. 2009, Lipsey and Naugle 2017).

\section{Vital rates across life-stages}

Nesting success, the most familiar and commonly measured vital rate during the breeding season, fell within established ranges in the Great Plains for Baird's Sparrow (17-43\%; Davis and Sealy 1998, Davis 2003, Jones et al. 2010, Lusk and Koper 2013, Davis et al. 2016b), and Grasshopper Sparrow (14-53\%; Berthelsen and Smith 1995, Jones et al. 2010, Hovick et al. 2012, Davis et al. 2016b). It is worth noting, however, that our estimate of Grasshopper Sparrow nesting success (16\%) fell on the extreme low end of reported estimates for the species, and yet success in that species was unresponsive to all environmental covariates we analyzed. Thus, additional exploration into the causes of low nesting success for this species in the NGP may be of value.

In contrast to nesting success, few studies have isolated adult survival on the breeding grounds in North American songbirds, making our results unique but also difficult to contextualize. Several mark-recapture studies examining annual survival in grassland songbirds species such as Bobolink, Savannah Sparrow, and Florida Grasshopper Sparrow report annual apparent survival typically between 40-60\% (Perkins and Vickery 2001, Fletcher et al. 2006, Perlut et al. 2008a, 2008b). However, our results are not directly comparable to these estimates, as our rates are confined to the breeding season period. Additionally, telemetry studies are better able to disentangle mortality from detectability than mark-recapture studies, which often suffer low recapture rates driven by poor site fidelity in grassland birds (Balent and Norment 2003, Fletcher et al. 2006, Jones et al. 2007). It is also important to note we were only able to track male birds, which may have biased our estimates. Male survivorship is sometime higher than female in grassland birds, and in songbirds generally (Perlut et al. 2008a, Low et al. 2010). This difference is likely a consequence of mortality incurred by females while on the nest. Nonetheless, our adult survival estimates for the breeding season were notably higher and more consistent than adult survival rates estimated for these species during other parts of their annual cycle (range 4-32\%; Macías-Duarte et al. 2017, 
Strasser et al. 2018) where winter survival for both species was influenced by environmental factors including precipitation and vegetative cover. Increasingly, there is evidence that substantial adult mortality may occur on the wintering grounds or during migration for some species (Hostetler et al. 2015). Studies of other migratory songbirds breeding in North America have shown that adult mortality is often highest during the migration period (Sillett and Holmes 2002, Rushing et al. 2017). Adult survival during the non-breeding periods of the annual cycle may therefore be of equal or greater importance to overall population growth than breeding season survival for our focal species.

Post-fledging survival has also been little studied in our focal species, but a growing number of studies examining survival of grassland songbird species during this critical life-history phase have been conducted over the past two decades. Our estimate of post-fledging survival in Baird's Sparrow $(25 \%)$ was similar to rates reported for closely related species such as Grasshopper Sparrow (21\%; Hovick et al. 2011), Henslow's Sparrow (25\%; Young et al. 2019), and Savannah Sparrow (21-35\%; van Vliet et al. 2020), though our own estimate of post-fledging survival in Grasshopper Sparrow was much higher (55\%). However, survival of fledgling Baird's Sparrow in our study was also lower than existing estimates for many other grassland obligates such as Dickcissel (Spiza americana; 56\%; Suedkamp Wells et al. 2007), Sprague's Pipit (29\%; Fisher and Davis 2011), Lark Bunting (27-37\%; Adams et al. 2006), and Eastern meadowlark (Sturnella magna; 63-69\%; Kershner et al. 2004, Suedkamp Wells et al. 2007). Further, survival estimates for Baird's Sparrow fell well below the $40 \%$ threshold theoretically necessary to maintain populations without unrealistically high survival during other demographic stages (Cox et al. 2014). Therefore, we suggest that post-fledging survival may be a management consideration for Baird's Sparrow and should be examined more frequently in conjunction with nesting success.

Monitoring multiple vital rates in avian populations of interest is critical not only for management purposes (Fletcher et al. 2006, Perlut et al. 2008b, van Vliet et al. 2020) but also for the creation of accurate population models (Streby and Andersen 2011). While informally comparing vital rates across life-history stages may be the first step in assessing overall population limitation for species, evaluating the relative impact of these seasonal vital rates on population trajectory through full annual cycle population models is necessary to fully understand limitation (Hostetler et al. 2015). Increasingly, avian researchers have shown the importance of assessing demographics across the full spatial and temporal life-cycles of species, and the potential for carryover and interaction between these stages (Latta et al. 2016, Rushing et al. 2017). Integrated population models (IPMs) are a powerful tool for identifying limiting life-stages and geographies, and making accurate population predictions with respect to broad changes in land use and climate (Ahrestani et al. 2017, Zhao et al. 2019). Importantly, for habitat limited species like grassland birds, such models can also be used to identify critical habitat areas (Grand et al. 2019). Although one appealing aspect of IPM's is the ability to estimate latent parameters for which data are lacking, such as survival during the migration period (Ahrestani et al. 2017), such models require large amounts of data from various life-stages. Therefore, accurate data describing fundamental vital rates across multiple life-history phases of species are a critical component of both management oriented and analytical conservation efforts.

\section{CONCLUSION}

While demographic monitoring of songbirds has traditionally focused on single vital rates (e.g., nesting success), more comprehensive approaches may yield greater insight into population dynamics (Rushing et al. 2017, Wilson et al. 2018). Our study is the first to simultaneously monitor nesting success, breeding-season adult survival, and post-fledging survival for two declining grassland songbird species in the NGP. We found that Baird's Sparrow demographics were more responsive to environmental conditions than in Grasshopper Sparrow, for which habitat covariates had little impact on vital rates. Both nesting success and post-fledging survival in Baird's Sparrow increased with vertical vegetation structure, and post-fledging survival in Baird's Sparrow was also negatively influenced by nonnative plant cover. Adult survival on the breeding grounds for both species was high and invariant relative to overwintering survival in the same species, indicating that breeding season adult survival in these populations may be of less conservation significance. By contrast, post-fledging survival in Baird's Sparrow was low, suggesting that management of juveniles may be a priority for further research and monitoring efforts. We suggest the combination of these data with other datasets from the nonbreeding grounds in full annual cycle models to formally compare seasonal vital rates with the ultimate goal of creating conservation goals inclusive of the entire life cycle for these declining species.

Responses to this article can be read online at: https://www.ace-eco.org/issues/responses.php/1875

\section{Acknowledgments:}

We would like to thank the U.S Forest Service, Medora District Office, the Bureau of Land Management, Glasgow Office, the Little Missouri Grazing Association, S. K. Sather and J. D. Sather, V. Stark, and G. Weinreis for allowing and coordinating site access. We also thank T. L. VerCauteren for internal support and funding. We thank Q. S. Latif, D. C. Pavlacky, and A. W. Green for statistical consultation. We also thank our hardworking technicians and interns for their labor and dedication in the field that made this research possible. Finally, we would like to thank our funders, including North Dakota Game and Fish Department (Wildlife and Sport Fish Restoration Program funds under the State Wildlife Grants Program CFDA\# 15.634), the National Fish and Wildlife Foundation (grant \#s 49599, 54873), the Bobolink Foundation, Montana Fish, Parks, \& Wildlife (\#16-615), U.S. Fish and Wildlife Region 6, the Prairie Potholes Join Venture, the Northern Great Plains Joint Venture, and the North Dakota Natural Resources Trust for directly supporting this research. The findings and conclusions in this article are those of the author $(s)$ and do not necessarily represent the views of the U.S. Fish and Wildlife Service

\section{LITERATURE CITED}

Adams, A. A. Y., S. K. Skagen, and R. D. Adams. 2001. Movements and survival of Lark Bunting fledglings. The Condor 103:643-647. https://doi.org/10.1093/condor/103.3.643 
Adams, A. A. Y., S. K. Skagen, and J. A. Savidge. 2006. Modeling post-fledging survival of Lark Buntings in response to ecological and biological factors. Ecology 87:178-188. https://doi. org/10.1890/04-1922

Ahrestani, F. S., J. F. Saracco, J. R. Sauer, K. L. Pardieck, and J. A. Royle. 2017. An integrated population model for bird monitoring in North America. Ecological Applications 27:916-924. https://doi.org/10.1002/eap.1493

Anders, A. D., and M. R. Marshall. 2005. Increasing the accuracy of productivity and survival estimates in assessing landbird population status. Conservation Biology 19:66-74. https://doi. org/10.1111/j.1523-1739.2005.00543.x

Arnold, T. W. 2010. Uninformative parameters and model selection using Akaike's information criterion. Journal of Wildlife Management 74:1175-1178. https://doi.org/10.1111/j.1937-2817.2010. tb01236.x

Askins, R. A., F. Chávez-Ramírez, B. C. Dale, C. A. Haas, J. R. Herkert, F. L. Knopf, and P. D. Vickery. 2007. Conservation of grassland birds in North America: understanding ecological processes in different regions: "Report of the AOU Committee on Conservation." Ornithological Monographs:1-46. https://doi. org/10.2307/40166905

Balent, K. L., and C. J. Norment. 2003. Demographic characteristics of a Grasshopper Sparrow population in a highly fragmented landscape of western New York State. Journal of Field Ornithology 74:341-348. https://doi.org/10.1648/0273-8570-74.4.341

Barnett, K. L., and S. L. Facey. 2016. Grasslands, invertebrates, and precipitation: a review of the effects of climate change. Frontiers in Plant Science 7:1-8. https://doi.org/10.3389/ fpls.2016.01196

Barron, D. G., J. D. Brawn, and P. J. Weatherhead. 2010. Metaanalysis of transmitter effects on avian behaviour and ecology. Methods in Ecology and Evolution 1:180-187. https://doi. org/10.1111/j.2041-210X.2010.00013.X

Barton, K. 2020. MuMIn: Multi-Model Inference. R package version 1.43.17. [online] URL: https://CRAN.R-project.org/ package $=$ MuMIn.

Bates, D., M. Mächler, B. Bolker, and S. Walker. 2015. Fitting linear mixed-effects models using lme4. Journal of Statistical Software 67:1-68. https://doi.org/10.18637/jss.v067.i01

Berkeley, L. I., J. P. McCarty, and L. L. Wolfenbarger. 2007. Postfledging survival and movement in Dickcissels (Spiza americana): implications for habitat management and conservation. The Auk 124:396-409. https://doi.org/10.1093/ auk/124.2.396

Bernath-Plaisted, J., and N. Koper. 2016. Physical footprint of oil and gas infrastructure, not anthropogenic noise, reduces nesting success of some grassland songbirds. Biological Conservation 204:434-441. https://doi.org/10.1016/j.biocon.2016.11.002

Berthelsen, P. S., and L. M. Smith. 1995. Nongame birds nesting on CRP lands in the Texas Southern High Plains. Journal of Soil and Water Conservation 50:672-675. [online] URL: https://www. jswconline.org/content/50/6/672
BirdLife International and NatureServe. 2016. Bird species distribution maps of the world. BirdLife International and NatureServe, Cambridge, UK and Arlington, Virginia, USA.

Bonnot, T. W., F. R. Thompson, and J. J. Millspaugh. 2011. Extension of landscape-based population viability models to ecoregional scales for conservation planning. Biological Conservation 144:2041-2053. https://doi.org/10.1016/j.biocon.2011.04.026

Border, J. A., L. R. Atkinson, I. G. Henderson, and I. R. Hartley. 2018. Nest monitoring does not affect nesting success of Whinchats Saxicola rubetra. Ibis 160:624-633. https://doi. org/10.1111/ibi.12574

Brennan, L. A., and W. P. Kuvlesky. 2005. North American grassland birds: an unfolding conservation crisis? Journal of Wildlife Management 69:1-13. https://doi.org/10.2193/0022-541x (2005)069<0001:nagbau>2.0.co;2

Burhans, D. E., D. Dearborn, F. R. Thompson, and J. Faaborg. 2002. Factors affecting predation at songbird nests in old fields. Journal of Wildlife Management 66:240-249. https://doi. org/10.2307/3802890

Burnham, K. P., and D. R. Anderson. 2002. Model selection and multimodel inference: a practical information-theoretic approach, 2nd edition. Springer Science, New York, NY, USA.

Burnham, K. P., D. R. Anderson, and K. P. Huyvaert. 2011. AIC model selection and multimodel inference in behavioral ecology: some background, observations, and comparisons. Behavioral Ecology and Sociobiology 65:23-35. https://doi.org/10.1007/ s00265-010-1029-6

Cade, B. S. 2015. Model averaging and muddled multimodel inferences. Ecology 96:2370-2382. https://doi.org/10.1890/14-1639.1

Carver, A. R., J. D. Ross, D. J. Augustine, S. K. Skagen, A. M. Dwyer, D. F. Tomback, and M. B. Wunder. 2017. Weather radar data correlate to hail-induced mortality in grassland birds. Remote Sensing in Ecology and Conservation 3:90-101. https://doi. org/10.1002/rse2.41

Chalfoun, A. D., and K. A. Schmidt. 2012. Adaptive breedinghabitat selection: is it for the birds? The Auk 129:589-599. https:// doi.org/10.1525/auk.2012.129.4.589

Clark, M. E., and T. E. Martin. 2007. Modeling tradeoffs in avian life history traits and consequences for population growth. Ecological Modelling 209:110-120. https://doi.org/10.1016/j. ecolmodel.2007.06.008

Comer, P. J., J. C. Hak, K. Kindscher, E. Muldavin, and J. Singhurst. 2018. Continent-scale landscape conservation design for temperate grasslands of the Great Plains and Chihuahuan Desert. Natural Areas Journal 38:196-211. https://doi. org/10.3375/043.038.0209

Conrey, R. Y., S. K. Skagen, A. A. Y. Adams, and A. O. Panjabi. 2016. Extremes of heat, drought and precipitation depress reproductive performance in shortgrass prairie passerines. Ibis 158:614-629. https://doi.org/10.1111/ibi.12373

Correll, M. D., E. H. Strasser, A. W. Green, and A. O. Panjabi. 2019. Quantifying specialist avifaunal decline in grassland birds 
of the Northern Great Plains. Ecosphere 10:e2523. https://doi. org/10.1002/ecs 2.2523

Cox, W. A., F. R. Thompson, A. S. Cox, and J. Faaborg. 2014. Post-fledging survival in passerine birds and the value of postfledging studies to conservation. Journal of Wildlife Management 78:183-193. https://doi.org/10.1002/jwmg.670

Crouse, D. T., L. B. Crowder, and H. Caswell. 1987. A stage-based population model for Loggerhead Sea Turtles and implications for conservation. Ecology 68:1412-1423. https://doi.org/10.2307/1939225

Daubenmire, R. F. 1959. Canopy coverage method of vegetation analysis. Northwest Science 33:43-64.

Davis, C. A., R. T. Churchwell, S. D. Fuhlendorf, D. M. Engle, and T. J. Hovick. 2016a. Effect of pyric herbivory on source-sink dynamics in grassland birds. Journal of Applied Ecology 53:1004-1012. https://doi.org/10.1111/1365-2664.12641

Davis, S. K. 2003. Nesting ecology of mixed-grass prairie songbirds in southern Saskatchewan. The Wilson Bulletin 115:119-130. https://doi.org/10.1676/02-138

Davis, S. K. 2005. Nest-site selection patterns and the influence of vegetation on nest survival of mixed-grass prairie passerines. The Condor 107:605-616. https://doi.org/10.1093/condor/107.3.605

Davis, S. K., R. M. Brigham, T. L. Shaffer, and P. C. James. 2006. Mixed-grass prairie passerines exhibit weak and variable responses to patch size. The Auk 123:807-821. https://doi. org/10.1093/auk/123.3.807

Davis, S. K., and R. J. Fisher. 2009. Post-fledging movements of Sprague's Pipit. The Wilson Journal of Ornithology 121:198-202. https://doi.org/10.1676/08-025.1

Davis, S. K., and T. G. Holmes. 2012. Sprague's Pipit incubation behavior. Pages 67-76 in C.A. Ribic, F. R. Thompson III, and P. J. Pietz, editors. Video surveillance of nesting birds. University of California Press, Berkeley CA. https://doi.org/10.1525/ california/9780520273139.003.0006

Davis, S. K., S. M. Ludlow, and D. G. McMaster. 2016 b. Reproductive success of songbirds and waterfowl in native mixedgrass pasture and planted grasslands used for pasture and hay. The Condor 118:815-834. https://doi.org/10.1650/condor-16-16.1 https://doi.org/10.1650/CONDOR-16-16.1

Davis, S. K., and S. G. Sealy. 1998. Nesting biology of the Baird's Sparrow in southwestern Manitoba. The Wilson Bulletin 110:262-270. [online] URL: https://www.jstor.org/stable/4163935

Derner, J. D., W. K. Lauenroth, P. Stapp, and D. J. Augustine. 2009. Livestock as ecosystem engineers for grassland bird habitat in the western Great Plains of North America. Rangeland Ecology \& Management 62:111-118. https://doi.org/10.2111/08-008.1

Dieni, J. S., and S. L. Jones. 2003. Grassland songbird nest site selection patterns in northcentral Montana. The Wilson Bulletin 115:388-396. https://doi.org/10.1676/03-055

Donovan, T. M., F. R. Thompson, J. Faaborg, and J. R. Probst. 1995. Reproductive success of migratory birds in habitat sources and sinks. Conservation Biology 9:1380-1395. https://doi. org/10.1046/j.1523-1739.1995.09061380.x
Eng, M. L., B. J. M. Stutchbury, D. M. Burke, and K. A. Elliott. 2011. Influence of forest management on pre- and post-fledging productivity of a neotropical migratory songbird in a highly fragmented landscape. Canadian Journal of Forest Research 41:2009-2019. d https://doi.org/10.1139/x11-119

Fisher, R. J., and S. K. Davis. 2010. From Wiens to Robel: a review of grassland-bird habitat selection. Journal of Wildlife Management 74:265-273. https://doi.org/10.2193/2009-020

Fisher, R. J., and S. K. Davis. 2011. Post-fledging dispersal, habitat use, and survival of Sprague's Pipits: are planted grasslands a good substitute for native? Biological Conservation 144:263-271. https://doi.org/10.1016/j.biocon.2010.08.024

Flanders, A. A., W. P. Kuvlesky, D. C. Ruthven, R. E. Zaiglin, R. L. Bingham, T. E. Fulbright, F. Hernández, and L. A. Brennan. 2006. Effects of invasive exotic grasses on south Texas rangeland breeding birds. The Auk 123:171-182. https://doi.org/10.1093/ auk/123.1.171

Fletcher, R. J., R. R. Koford, and D. A. Seaman. 2006. Critical demographic parameters for declining songbirds breeding in restored grasslands. Journal of Wildlife Management 70:145-157. https://doi.org/10.2193/0022-541X(2006)70[145:CDPFDS]2.0.CO;2

Fondell, T. F., and I. J. Ball. 2004. Density and success of bird nests relative to grazing on western Montana grasslands. Biological Conservation 117:203-213. https://doi.org/10.1016/ S0006-3207(03)00293-3

George, T. L., A. C. Fowler, R. L. Knight, and L. C. McEwen. 1992. Impacts of a severe drought on grassland birds in western North Dakota. Ecological Applications 2:275-284. https://doi. org/10.2307/1941861

Graham, M. H. 2003. Confronting multicollinearity in ecological multiple regression. Ecology 84:2809-2815. https://doi.org/10.1890/02-3114

Grand, J., C. Wilsey, J. X. Wu, and N. L. Michel. 2019. The future of North American grassland birds: incorporating persistent and emergent threats into full annual cycle conservation priorities. Conservation Science and Practice 1:e20. https://doi.org/10.1111/ $\operatorname{csp} 2.20$

Grant, T. A., and T. L. Shaffer. 2012. Time-specific patterns of nest survival for ducks and passerines breeding in North Dakota. The Auk 129:319-328. https://doi.org/10.1525/auk.2012.11064

Grant, T. A., T. L. Shaffer, E. M. Madden, and P. J. Pietz. 2005. Time-specific variation in passerine nest survival: new insights into old questions. The Auk 122:661-672. https://doi.org/10.1093/ auk/122.2.661

Green, M.T., P.E. Lowther, S.L. Jones, S.K. Davis, B.C. Dale. 2002. Baird's Sparrow (Ammodramus bairdii). Birds of North America. Cornell Lab of Ornithology, Ithaca, New York. https:// doi.org/10.2173/bna.638.

Green, A. W., M. D. Correll, T. L. George, I. Davidson, S. Gallagher, C. West, A. Lopata, D. Casey, K. Ellison, D. C. Pavlacky, L. Quattrini, A. E. Shaw, E. H. Strasser, T. VerCauteren, and A. O. Panjabi. 2018. Using structured decision making to prioritize species assemblages for conservation. Journal for Nature Conservation 45:48-57. https://doi.org/10.1016/j.jnc.2018.08.003 
Guido, A. 2020. Habitat selection across the reproductive cycles of grassland songbirds in the Northern Great Plains. Masters thesis. Univeristy of Maine. [online] URL: https://digitalcommons. library.umaine.edu/etd/3217

Hickman, K. R., G. H. Farley, R. Channell, and J. E. Steier. 2006. Effects of old world bluestem (Bothriochloa ischaemum) on food availability and avian community composition within the mixedgrass prairie. The Southwestern Naturalist 51:524-530. https://doi. org/10.1894/0038-4909(2006)51[524:EOOWBB]2.0.CO;2

Hill, J. M., J. F. Egan, G. E. Stauffer, and D. R. Diefenbach. 2014. Habitat availability is a more plausible explanation than insecticide acute toxicity for U.S. grassland bird species declines. PLOS ONE 9. https://doi.org/10.1371/journal.pone.0098064

Hostetler, J. A., T. S. Sillett, and P. P. Marra. 2015. Full-annualcycle population models for migratory birds. The Auk 132:433-449. https://doi.org/10.1642/AUK-14-211.1

Hovick, T. J., J. R. Miller, S. J. Dinsmore, D. M. Engle, D. M. Debinski, and S. D. Fuhlendorf. 2012. Effects of fire and grazing on Grasshopper Sparrow nest survival. Journal of Wildlife Management 76:19-27. https://doi.org/10.1002/jwmg.243

Hovick, T. J., J. R. Miller, R. R. Koford, D. M. Engle, and D. M. Debinski. 2011. Postfledging survival of Grasshopper Sparrows in grasslands managed with fire and grazing. The Condor 113:429-437. https://doi.org/10.1525/cond.2011.100135

Jones, S. L., J. S. Dieni, and P. J. Gouse. 2010. Reproductive biology of a grassland songbird community in northcentral Montana. The Wilson Journal of Ornithology 122:455-464. https://doi.org/10.1676/08-171.1

Jones, S. L., J. S. Dieni, M. T. Green, and P. J. Gouse. 2007. Annual return rates of breeding grassland songbirds. The Wilson Journal of Ornithology 119:89-94. https://doi.org/10.1676/05-158.1

Jones, T. M., M. P. Ward, T. J. Benson, and J. D. Brawn. 2017. Variation in nestling body condition and wing development predict cause-specific mortality in fledgling Dickcissels. Journal of Avian Biology 48:439-447. https://doi.org/10.1111/jav.01143

Jones, Z. F., and C. E. Bock. 2005. The Botteri's Sparrow and exotic Arizona grasslands: an ecological trap or habitat regained? The Condor 107:731-741. https://doi.org/10.1093/condor/107.4.731

Jongsomjit, D., S. L. Jones, T. Gardali, G. R. Geupel, and P. J. Gouse. 2007. A guide to nestling development and aging in altricial passerines. Pages 1-56. U.S. Department of the Interior, Fish and Wildlife Service, Washington D.C., USA.

Kerns, C. K., M. R. Ryan, R. K. Murphy, F. R. Thompson, and C. S. Rubin. 2010. Factors affecting songbird nest survival in northern mixed-grass prairie. Journal of Wildlife Management 74:257-264. https://doi.org/10.2193/2008-249

Kershner, E. L., J. W. Walk, and R. E. Warner. 2004. Postfledging movements and survival of juvenile Eastern Meadowlarks (Sturnella magna) in Illinois. The Auk 121:1146-1154. https://doi. org/10.1642/0004-8038(2004)121[1146:PMASOJ]2.0.CO;2

Kirkham, C. B. S., and S. K. Davis. 2013. Incubation and nesting behaviour of the Chestnut-collared Longspur. Journal of Ornithology 154:795-801. https://doi.org/10.1007/s10336-013-0945-4
Klug, P. E., S. L. Jackrel, and K. A. With. 2010. Linking snake habitat use to nest predation risk in grassland birds: the dangers of shrub cover. Oecologia 162:803-813. https://doi.org/10.1007/ s00442-009-1549-9

Koper, N., and F. K. A. Schmiegelow. 2007. Does management for duck productivity affect songbird nesting success? Journal of Wildlife Management 71:2249-2257. https://doi.org/10.2193/2006-354

Latta, S. C., S. Cabezas, D. A. Mejia, M. M. Paulino, H. Almonte, C. M. Miller-Butterworth, and G. R. Bortolotti. 2016. Carry-over effects provide linkages across the annual cycle of a neotropical migratory bird, the Louisiana waterthrush Parkesia motacilla. Ibis 158:395-406. https://doi.org/10.1111/ibi.12344

Lebreton, J.-D., K. P. Burnham, J. Clobert, and D. R. Anderson. 1992. Modeling survival and testing biological hypotheses using marked animals: a unified approach with case studies. Ecological Monographs 62:67-118. https://doi.org/10.2307/2937171

Lipsey, M. K., and D. E. Naugle. 2017. Precipitation and soil productivity explain effects of grazing on grassland songbirds. Rangeland Ecology \& Management 70:331-340. https://doi. org/10.1016/j.rama.2016.10.010

Lloyd, J. D., and T. E. Martin. 2005. Reproductive success of Chestnut-collared Longspurs in native and exotic grassland. The Condor 107:363-374. https://doi.org/10.1093/condor/107.2.363

Low, M., D. Arlt, S. Eggers, and T. Pärt. 2010. Habitat-specific differences in adult survival rates and its links to parental workload and on-nest predation. Journal of Animal Ecology 79:214-224. https://doi.org/10.1111/j.1365-2656.2009.01595.x

Ludlow, S. M., R. M. Brigham, and S. K. Davis. 2015. Oil and natural gas development has mixed effects on the density and reproductive success of grassland songbirds. The Condor 117:64-75. https://doi.org/10.1650/CONDOR-14-79.1

Lusk, J. S., and N. Koper. 2013. Grazing and songbird nest survival in southwestern Saskatchewan. Rangeland Ecology \& Management 66:401-409. https://doi.org/10.2111/REM-D-11-00203.1

Macías-Duarte, A., A. O. Panjabi, E. H. Strasser, G. J. Levandoski, I. Ruvalcaba-Ortega, P. F. Doherty, and C. I. OrtegaRosas. 2017. Winter survival of North American grassland birds is driven by weather and grassland condition in the Chihuahuan Desert. Journal of Field Ornithology 88:374-386. https://doi. org/10.1111/jofo. 12226

Major, R. E. 1990. The effect of human observers on the intensity of nest predation. Ibis 132:608-612. https://doi.org/10.1111/ j.1474-919X.1990.tb00285.x

Manolis, J. C., D. E. Andersen, and F. J. Cuthbert. 2000. Uncertain nest fates in songbird studies and variation in Mayfield estimation. The Auk 117:615-626. https://doi.org/10.1093/ auk/117.3.615

Martin, T. E., and G. R. Geupel. 1993. Nest-monitoring plots: methods for locating nests and monitoring success. Journal of Field Ornithology 64:507-519. [online] URL: https://www.jstor. org/stable/4513862

McCauley, L. A., C. A. Ribic, L. Y. Pomara, and B. Zuckerberg. 2017. The future demographic niche of a declining grassland bird 
Avian Conservation and Ecology 16(1): 19

fails to shift poleward in response to climate change. Landscape Ecology 32:807-821. https://doi.org/10.1007/s10980-017-0487-x

McCoy, T. D., M. R. Ryan, E. W. Kurzejeski, and L. W. Burger. 1999. Conservation Reserve Program: source or sink habitat for grassland birds in Missouri? Journal of Wildlife Management 63:530-538. https://doi.org/10.2307/3802639

Murdoch, W. W. 1994. Population regulation in theory and practice. Ecology 75:271-287. https://doi.org/10.2307/1939533

Murphy, M. T. 2003. Avian population trends within the evolving agriculture landscape of eastern and central United States. The Auk 120:20-34. https://doi.org/10.1642/0004-8038(2003)120[0020: APTWTE]2.0.CO;2

North American Bird Conservation Initiative. 2009. The state of the birds, United States of America, 2009. Pages 1-36. U.S. Department of the Interior, Washington D.C., USA.

North American Bird Conservation Initiative. 2013. State of the birds 2013 report on private lands. Pages 1-48. U.S. Department of the Interior, Washington D.C., USA.

O'Grady, D. R., D. P. Hill, and R. M. R. Barclay. 1996. Nest visitation by humans does not increase predation on chestnutcollared longspur eggs and young. Journal of Field Ornithology 67:275-280. [online] URL: https://www.jstor.org/stable/4514108

Partners in Flight. 2020. Avian Conservation Assessment Database Global Assessment. http://pif.birdconservancy.org/\#. Accessed 24 March, 2021.

Perkins, D. W., and P. D. Vickery. 2001. Annual survival of an endangered passerine, the Florida Grasshopper Sparrow. The Wilson Bulletin 113:211-216. https://doi.org/10.1676/0043-5643 (2001)113[0211:ASOAEP]2.0.CO;2

Perlut, N. G., A. M. Strong, T. M. Donovan, and N. J. Buckley. 2008a. Grassland songbird survival and recruitment in agricultural landscapes: implications for source-sink demography. Ecology 89:1941-1952. https://doi.org/10.1890/07-0900.1

Perlut, N. G., A. M. Strong, T. M. Donovan, and N. J. Buckley. 2008b. Regional population viability of grassland songbirds: effects of agricultural management. Biological Conservation 141:3139-3151. https://doi.org/10.1016/j.biocon.2008.09.011

Pietz, P. J., D. A. Granfors, and T. A. Grant. 2012. Hatching and fledging times from grassland passerine nests. Pages 47-60 in C. A. Ribic and F. R. Thompson III, editors. Video Surveillance of Nesting Birds. University of California Press. https://doi. org/10.1525/california/9780520273139.003.0004

Pipher, E. N., C. M. Curry, and N. Koper. 2016. Cattle grazing intensity and duration have varied effects on songbird nest survival in mixed-grass prairies. Rangeland Ecology \& Management 69:437-443. https://doi.org/10.1016/j.rama.2016.07.001

Pool, D. B., A. O. Panjabi, A. Macias-Duarte, and D. M. Solhjem. 2014. Rapid expansion of croplands in Chihuahua, Mexico threatens declining North American grassland bird species. Biological Conservation 170:274-281. https://doi.org/10.1016/j. biocon.2013.12.019
Pulliam, H. R. 1988. Sources, sinks, and population regulation. The American Naturalist 132:652-661. https://doi.org/10.1086/284880

Pulliam, H. R., J. B. Dunning, and J. Liu. 1992. Population dynamics in complex landscapes: a case study. Ecological Applications 2:165-177. https://doi.org/10.2307/1941773

R Core Team. 2020. R: A language and environment for statistical computing. R

Foundation for Statistical Computing, Vienna, Austria. [online] URL: https://www.R-project.org/.

Rappole, J. H., and A. R. Tipton. 1991. New harness design for attachment of radio transmitters to small passerines. Journal of Field Ornithology 62:335-337. [online] URL: https://www.jstor. org/stable/20065798

Robel, R. J., J. N. Briggs, A. D. Dayton, and L. C. Hulbert. 1970. Relationships between visual obstruction measurements and weight of grassland vegetation. Journal of Range Management 23:295. https://doi.org/10.2307/3896225

Rosenberg, K. V., A. M. Dokter, P. J. Blancher, J. R. Sauer, A. C. Smith, P. A. Smith, J. C. Stanton, A. Panjabi, L. Helft, M. Parr, and P. P. Marra. 2019. Decline of the North American avifauna. Science 366:120-124. https://doi.org/10.1126/science.aaw1313

Rush, S. A., and B. J. M. Stutchbury. 2008. Survival of fledgling Hooded Warblers (Wilsonia citrina) in small and large forest fragments. The Auk 125:183-191. https://doi.org/10.1525/ auk.2008.125.1.183

Rushing, C. S., J. A. Hostetler, T. S. Sillett, P. P. Marra, J. A. Rotenberg, and T. B. Ryder. 2017. Spatial and temporal drivers of avian population dynamics across the annual cycle. Ecology 98:2837-2850. https://doi.org/10.1002/ecy.1967

Ruth, J. M., and J. Kitting. 2018. Nestling development and aging of Arizona grasshopper sparrow. Journal of Arizona Field Ornithologists 2018:1-13. [online] URL: https://pubs.er.usgs.gov/ publication/70198892

Sauer, J. R., D. K. Niven, J. E. Hines, D. J. Ziolkowski, Jr, K. L. Pardieck, J. E. Fallon, and W. A. Link. 2017. The North American Breeding Bird Survey, Results and Analysis 1966 - 2015. Version 2.07.2017. USGS Patuxent Wildlife Research Center, Laurel, MD.

Schielzeth, H. 2010. Simple means to improve the interpretability of regression coefficients. Methods in Ecology and Evolution 1:103-113. https://doi.org/10.1111/j.2041-210X.2010.00012.x

Shaffer, T. L. 2004. A unified approach to analyzing nesting success. The Auk 121:15.

Sillett, T. S., and R. T. Holmes. 2002. Variation in survivorship of a migratory songbird throughout its annual cycle. Journal of Animal Ecology 71:296-308. https://doi.org/10.1046/ j.1365-2656.2002.00599.x

Skagen, S. K., and A. A. Y. Adams. 2012. Weather effects on avian breeding performance and implications of climate change. Ecological Applications 22:1131-1145. https://doi.org/10.1890/11-0291.1 
Small, D. M., P. J. Blank, and B. Lohr. 2015. Habitat use and movement patterns by dependent and independent juvenile Grasshopper Sparrows during the post-fledging period. Journal of Field Ornithology 86:17-26. https://doi.org/10.1111/jofo. 12085

Stahl, J. T., and M. K. Oli. 2006. Relative importance of avian life-history variables to population growth rate. Ecological Modelling 198:23-39. https://doi.org/10.1016/j.ecolmodel.2006.04.001

Steele, B. B. 1993. Selection of foraging and nesting sites by Blackthroated Blue Warblers: their relative influence on habitat choice. The Condor 95:568-579. https://doi.org/10.2307/1369601

Strasser, E. H., M.D. Correll, T. L. George, and A.O. Panjabi. 2018. Identifying limiting factors for wintering grassland birds in the Chihuahuan Desert. 2018 annual report. Bird Conservancy of the Rockies, Brighton, Colorado, USA.

Streby, H. M., and D. E. Andersen. 2011. Seasonal productivity in a population of migratory songbirds: why nest data are not enough. Ecosphere 2:art78. https://doi.org/10.1890/ES10-00187.1

Streby, H. M., and D. E. Andersen. 2013a. Testing common assumptions in studies of songbird nest success. Ibis 155:327-337. https://doi.org/10.1111/ibi.12018

Streby, H. M., and D. E. Andersen. 2013b. Survival of fledgling Ovenbirds: influences of habitat characteristics at multiple spatial scales. The Condor 115:403-410. https://doi.org/10.1525/ cond.2013.110178

Suedkamp Wells, K. M., M. R. Ryan, and J. J. Millspaugh. 2007. Survival of postfledging grassland birds in Missouri. The Condor 109:781-794. https://doi.org/10.1093/condor/109.4.781

Titulaer, M., A. Melgoza-Castillo, A. Macías-Duarte, and A. O. Panjabi. 2018. Seed size, bill morphology, and handling time influence preferences for native vs. nonnative grass seeds in three declining sparrows. The Wilson Journal of Ornithology 130:445-456. https://doi.org/10.1676/17-003.1

Verhulst, S., and J.-Å. Nilsson. 2008. The timing of birds' breeding seasons: a review of experiments that manipulated timing of breeding. Philosophical Transactions of the Royal Society B: Biological Sciences 363:399-410. https://doi.org/10.1098/rstb.2007.2146

van Vliet, H. E. J., B. J. M. Stutchbury, A. E. M. Newman, and D. R. Norris. 2020. The impacts of agriculture on an obligate grassland bird of North America. Agriculture, Ecosystems \& Environment 287:106696. https://doi.org/10.1016/j.agee.2019.106696

Vickery, P. D., 1996. Grasshopper Sparrow (Ammodramus savannarum). Birds of North America. Cornell Lab of Ornithology, Ithaca, NY, USA. https://doi.org/10.2173/bna.2
Wheelwright, N. T., and C. B. Schultz. 1994. Age and reproduction in Savannah Sparrows and Tree Swallows. Journal of Animal Ecology 63:686-702. https://doi.org/10.2307/5234

Williams, E. J., and W. A. Boyle. 2018. Patterns and correlates of within-season breeding dispersal: a common strategy in a declining grassland songbird. The Auk 135:1-14. https://doi. org/10.1642/AUK-17-69.1

Wilson, S., J. F. Saracco, R. Krikun, D. T. T. Flockhart, C. M. Godwin, and K. R. Foster. 2018. Drivers of demographic decline across the annual cycle of a threatened migratory bird. Scientific Reports 8:7316. https://doi.org/10.1038/s41598-018-25633-z

Winter, M. 1999. Nesting biology of Dickcissels and Henslow's Sparrows in southwestern Missouri prairie fragments. The Wilson Bulletin 111:515-526. [online] URL: https://www.jstor.org/ stable/4164137

Winter, M., S. E. Hawks, J. A. Shaffer, and D. H. Johnson. 2003. Guidelines for finding nests of passerine birds in Tallgrass Prairie:16.

Young, A. C., W. A. Cox, J. P. McCarty, and L. L. Wolfenbarger. 2019. Postfledging habitat selection and survival of Henslow's Sparrow: management implications for a critical life stage. Avian Conservation and Ecology 14(2):10. https://doi.org/10.5751/ ace-01418-140210

Youngberg, E. N., A. R. Bankert, A. O. Panjabi, R. Y. Conrey, A. Meyer, and M. D. Correll. 2020. Southward breeding range expansion of the Baird's Sparrow. Ecology 101:e02872. https:// doi.org/10.1002/ecy. 2872

Zhao, Q., T. W. Arnold, J. H. Devries, D. W. Howerter, R. G. Clark, and M. D. Weegman. 2019. Land-use change increases climatic vulnerability of migratory birds: insights from integrated population modelling. Journal of Animal Ecology 88:1625-1637. https://doi.org/10.1111/1365-2656.13043

Zimmerman, J. L. 1984. Nest predation and its relationship to habitat and nest density in dickcissels. The Condor 86:68-72. https://doi.org/10.2307/1367348

Zuckerberg, B., C. A. Ribic, and L. A. McCauley. 2018. Effects of temperature and precipitation on grassland bird nesting success as mediated by patch size. Conservation Biology 32:872-882. https://doi.org/10.1111/cobi.13089
Editor-in-Chief: Keith A.Hobson Subject Editor: Wayne E.Thogmartin

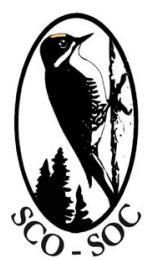

Sponsored by the Society of Canadian Ornithologists and Birds Canada

Parrainée par la Société des ornithologistes du Canada et Oiseaux Canada 


\section{Appendix 1}

Table A.1.1. Mean $(S D)$ vegetation structure and cover measurements for 5-m radius ocular surveys at two pastures in western North Dakota and two pastures in northeastern Montana, 2016-2018. We conducted vegetation surveys across a 100-m grid on each pasture in both early- (May-June) and late- (July-August) season for a total of 3637 surveys.

\begin{tabular}{|c|c|c|c|c|c|c|c|c|c|}
\hline Year & Pasture & VOR (cm) & Height $(\mathrm{cm})$ & Cover $(\%)$ & Grass (\%) & Forb (\%) & Shrub (\%) & Bare $(\%)$ & Litter $(\%)$ \\
\hline \multirow[t]{4}{*}{2016} & MT 1 & $10.5(5.5)$ & $24(11)$ & $91(8)$ & $71(16)$ & $18(12)$ & $2(7)$ & $6(7)$ & $3(2)$ \\
\hline & MT 2 & $10.0(7.8)$ & $25(12)$ & $86(12)$ & 65 (17) & $19(12)$ & $3(8)$ & $9(10)$ & $4(3)$ \\
\hline & ND 1 & $7.0(3.9)$ & $19(7)$ & 84 (16) & $76(18)$ & $8(7)$ & $0(1)$ & $5(11)$ & $10(12)$ \\
\hline & ND 2 & $5.5(3.6)$ & $19(6)$ & 74 (17) & 65 (19) & $9(8)$ & $0(0)$ & $7(10)$ & $19(15)$ \\
\hline \multirow[t]{4}{*}{2017} & MT 1 & $7.5(3.5)$ & $16(5)$ & $84(10)$ & 69 (16) & $13(10)$ & $1(5)$ & $9(10)$ & $7(5)$ \\
\hline & MT 2 & $9.0(5.8)$ & $17(8)$ & $83(14)$ & 70 (17) & $11(8)$ & $2(6)$ & $10(11)$ & $6(5)$ \\
\hline & ND 1 & $6.0(3.5)$ & $22(8)$ & 87 (13) & 77 (14) & $9(7)$ & $1(2)$ & $8(12)$ & $5(5)$ \\
\hline & ND 2 & $3.5(2.5)$ & $19(6)$ & 78 (14) & $69(15)$ & $9(8)$ & $0(1)$ & $14(13)$ & $7(6)$ \\
\hline \multirow[t]{4}{*}{2018} & MT 1 & $5.5(4.1)$ & $17(8)$ & $62(23)$ & $48(24)$ & $12(9)$ & $1(3)$ & $35(24)$ & $4(3)$ \\
\hline & MT 2 & $5.5(4.1)$ & $17(6)$ & $70(23)$ & $57(24)$ & $10(12)$ & $3(10)$ & $24(23)$ & $5(6)$ \\
\hline & ND 1 & $8.0(6.3)$ & $20(9)$ & $82(14)$ & $70(16)$ & $11(9)$ & $1(2)$ & $12(13)$ & $5(4)$ \\
\hline & ND 2 & $7.0(5.7)$ & $20(9)$ & $75(13)$ & $66(13)$ & $9(6)$ & $1(1)$ & $20(13)$ & $5(4)$ \\
\hline
\end{tabular}




\section{Appendix 2}

Figure A2.1. Mean cumulative distance traveled for fledgling Baird's Sparrows in western North Dakota and northeastern Montana, 2016-2018, from the nest (A) and from previous day's location (B). Bold lines denote median, filled circles denote mean, open circles are outliers, and top and bottom hinges display first and third quartiles (25th and 75 th percentiles); sample sizes are given in parentheses by day.

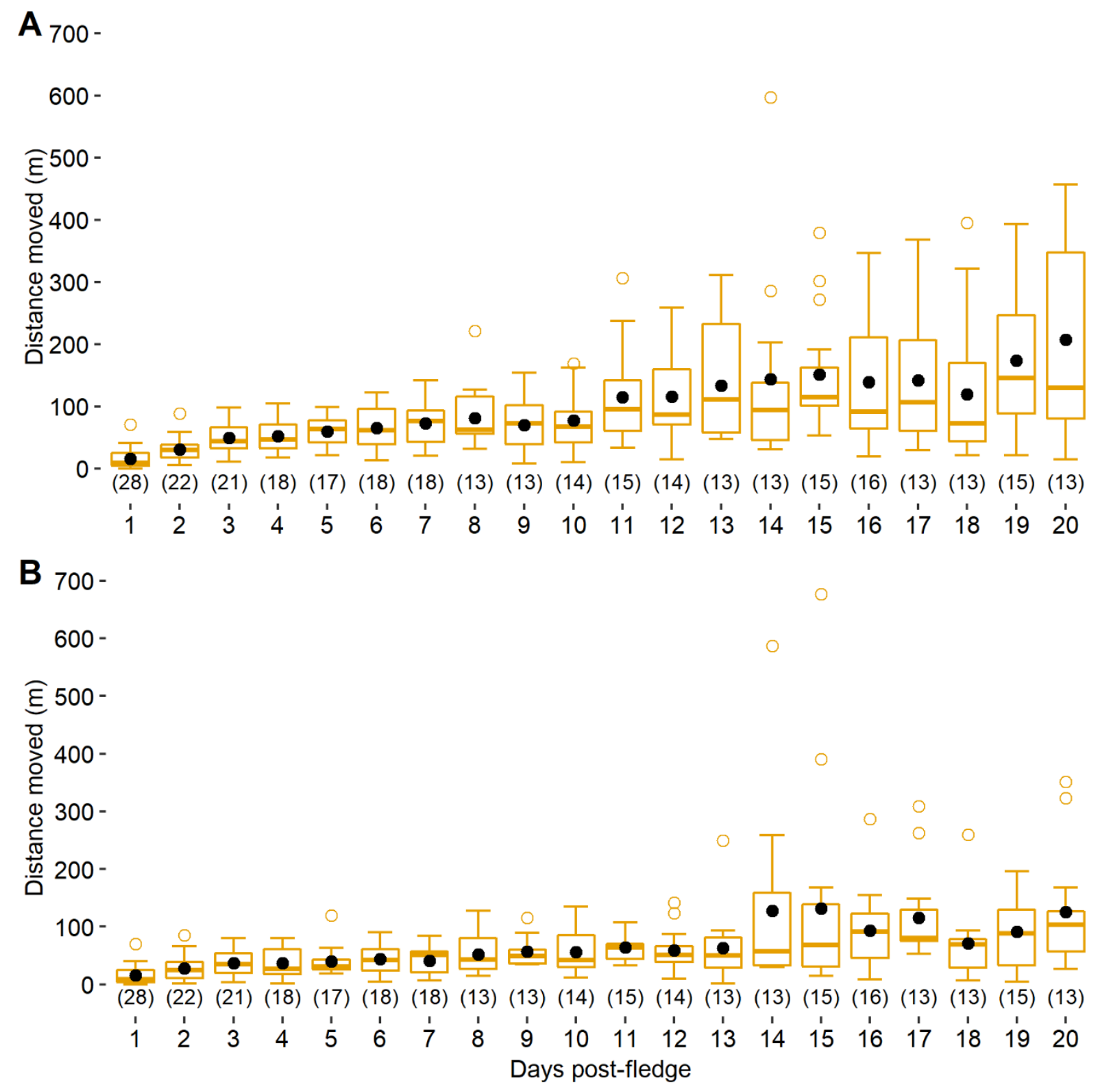


Figure A2.2. Mean cumulative distance traveled for fledgling Grasshopper Sparrows in western North Dakota and northeastern Montana, 2016-2018, from the nest (A) and from previous day's location (B). Bold lines denote median, filled circles denote mean, open circles are outliers, and top and bottom hinges display first and third quartiles (25th and 75th percentiles); sample sizes are given in parentheses by day.

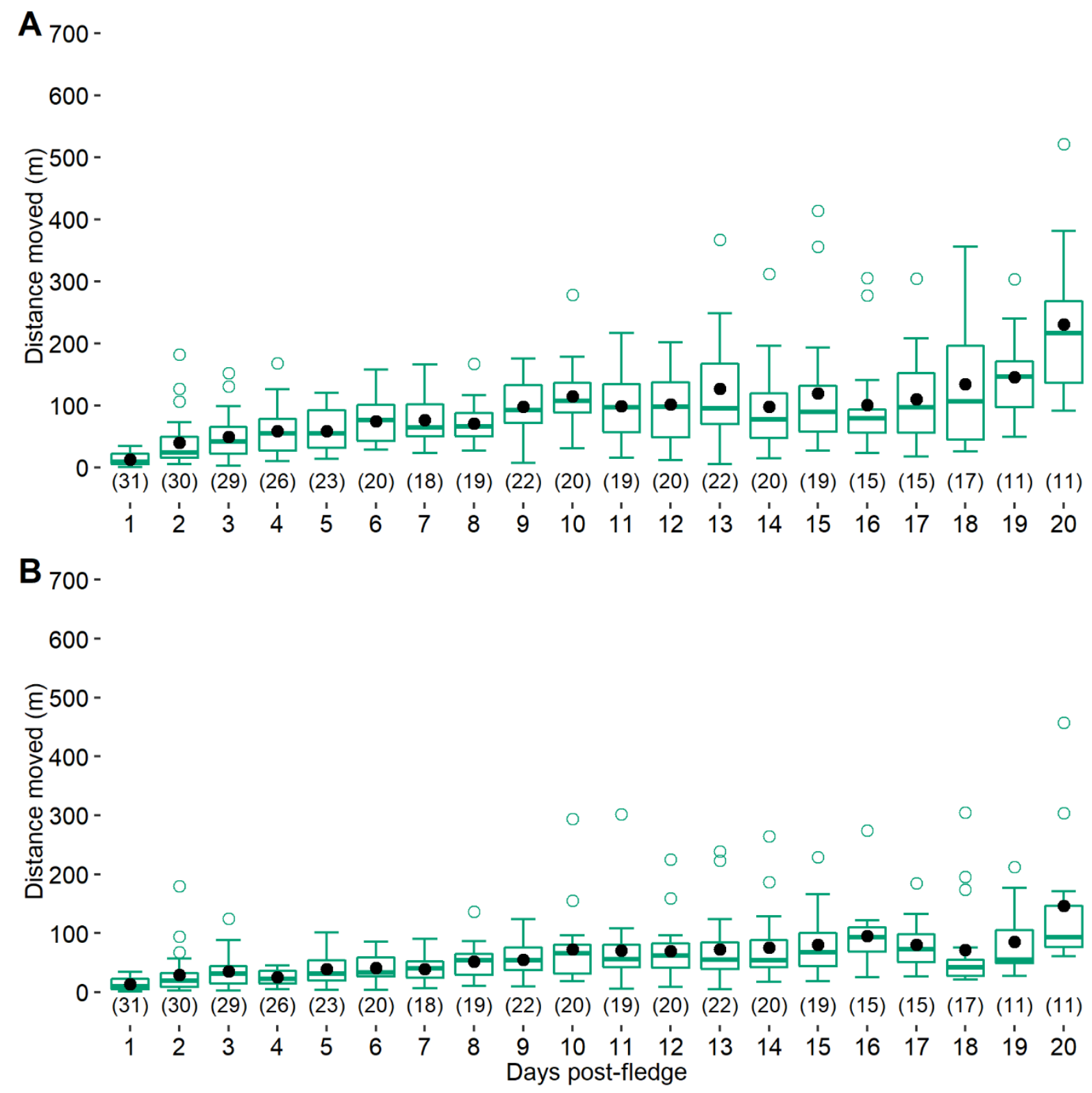




\section{Appendix 3}

Figure A3.1. Nest initiation density (distribution plots; left axes) and counts (histograms; right axes) by date for Baird's Sparrow (A; $n=139$ ) and Grasshopper Sparrow (B; $n=161)$, breeding in western North Dakota (2015-2018), and northeastern Montana (2016-2018). Initiation dates were back-calculated from hatch dates and nestling ages.
A.10-
$\mathbf{B}_{0.08}-$

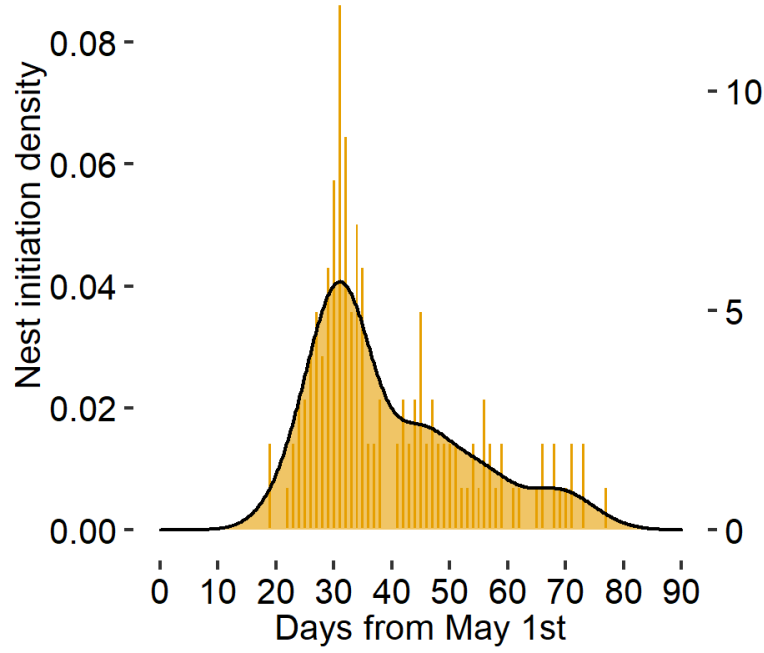
$0.06-$
$-10$
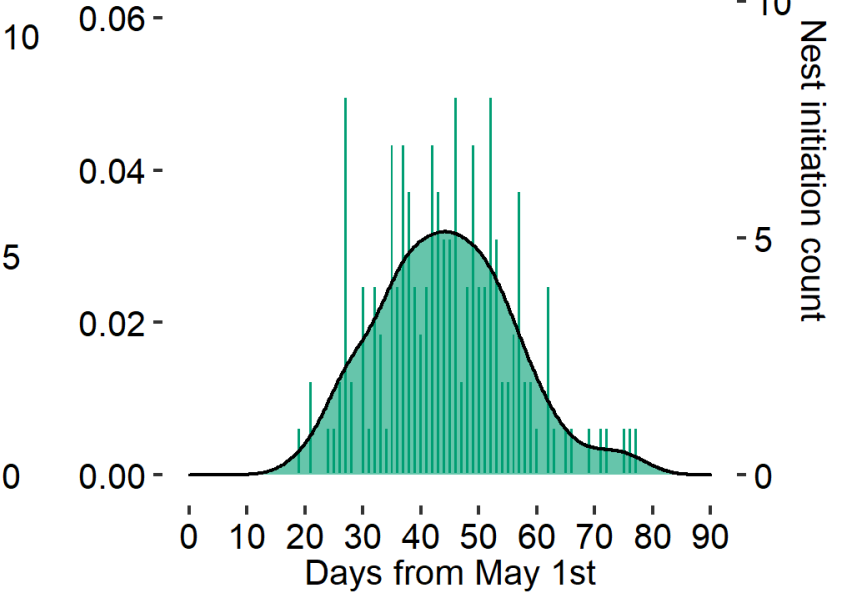